\title{
The Molecular Mechanism of the Insulin-mimetic/ sensitizing Activity of the Antidiabetic Sulfonylurea Drug Amaryl
}

\author{
Günter Müller \\ Aventis Pharma Germany, Frankfurt, Germany \\ Accepted August 8, 2000.
}

\begin{abstract}
The hypoglycemic sulfonylurea drugs cause reduction of blood glucose predominantly via stimulation of insulin release from pancreatic $\beta$ cells. In addition, during long-term treatment, an insulin-independent blood glucose-decreasing mechanism is assumed to operate. This may include insulin-sensitizing and insulin-mimetic activity in muscle and adipose tissue. This review summarizes our current knowledge about the putative modes of action of the sulfonylurea compound, Amaryl, in pancreatic $\beta$ cells and, in particular, peripheral target cells that form the molecular basis for its characteristic pharmacological and clinical profile. The analysis was performed in comparison with the conventional and the "golden standard" sulfonylurea, glibenclamide. I conclude: (I) The blood glucose decrease provoked by Amaryl can be explained by a combination of stimulation of insulin release from the pancreas and direct enhancement, as well as potentiation of the insulin response of glucose utilization in peripheral tissues only. (II) The underlying molecular mechanisms
\end{abstract}

seemed to rely on $\beta$ cells on a sulfonylurea receptor protein, SURX, associated with the ATP-sensitive potassium channel $\left(\mathrm{K}_{\mathrm{ATP}}\right)$ and different from SUR 1 for glibenclamide, and in muscle and adipose cells on: (a) the increased production of diacylglycerol and activation of protein kinase C; (b) the enhanced expression of glucose transporter isoforms; and (c) the insulin receptor-independent activation of the insulin receptor substrate/phosphatidylinositol3-kinase pathway. (III) The latter mechanism involved a nonreceptor tyrosine kinase and a number of components, such as caveolin and glycosylphosphatidylinositol structures, which are assembled in caveolae/detergent-insoluble glycolipid-enriched rafts of the target cell plasma membrane. Since hyperinsulinism and permanent $\mathrm{K}_{\mathrm{ATP}}$ closure are supposed to negatively affect the pathogenesis and therapy of non-insulin-dependent diabetes mellitus, the demonstrated higher insulin-independent blood glucose-lowering activity of Amaryl may be therapeutically relevant.

\section{Introduction}

It is now evident from numerous biochemical, genetic, and clinical studies that multiple gene defects and polymorphisms, in combination with physiological consequences of the typical western life style (nutrition, fitness, obesity),

Address correspondence and reprint requests to: Dr. Günter Müller, Aventis Pharma Germany, DG Metabolic Diseases, Bldg. H825, 65926 Frankfurt am Main, Germany. Phone: 4969-305-4271; Fax: 4969-30581767; E-mail: Guenter.Mueller@aventis.com impair the functionality of the triad, $\beta$ cell, muscle/adipose cell and liver cell, that regulate glucose and lipid metabolism. This results in reduced insulin secretion, reduced insulin sensitivity (insulin resistance), and increased hepatic glucose output, although their causal relationship remains a matter of intense debate. The hallmarks of increased fasting blood glucose levels, inadequate plasma insulin levels, impaired glucose tolerance, and misregulated lipid metabolism fuel a vicious cycle that, over 
decades, leads to the development of frank diabetes with the consequence of diabetic late complications (neuropathy, retinopathy, nephropathy, micro- and macroangiopathies, and cardiovascular diseases).

Sulfonylureas have been introduced into the therapy of non-insulin-dependent diabetes mellitus (NIDDM) with great success (1). It is now generally accepted that these hypoglycemic drugs cause reduction of blood glucose predominantly via stimulation of insulin release from pancreatic $\beta$ cells. In addition, during longterm treatment, an insulin-independent blood glucose-decreasing mechanism may operate. Its physiological role in diabetes therapy remains controversial and seems to be rather limited to conventional sulfonylureas (1). The predominant $\beta$-cell inherent mode of conventional sulfonylurea action may be responsible for some of the well-established, as well as hypothetical, problems with sulfonylurea therapy. The high plasma insulin levels may accelerate the pathogenesis of metabolic syndrome and NIDDM via a combination of pancreatic (exhaustion of the $\beta$ cell) and peripheral mechanisms (insulin resistance, lipid disorders, obesity, increased blood pressure, and atherosclerosis). In conjunction with limited selectivity for the $\beta$ cell, high plasma insulin levels may cause cardiovascular side effects. Furthermore, conventional sulfonylureas have to be administered several times per day.

In the following, I want to demonstrate that the sulfonylurea, Amaryl, despite harboring the typical sulfonylurea moiety (Fig. 1) and sharing the wide spectrum of in vitro (cell-free and cellular) activities attributed to conventional so-called first- (such as tolbutamide) and second-generation sulfonylureas (such as the "golden standard," glibenclamide) to a certain degree, operates at both the $\beta$-cell and cells

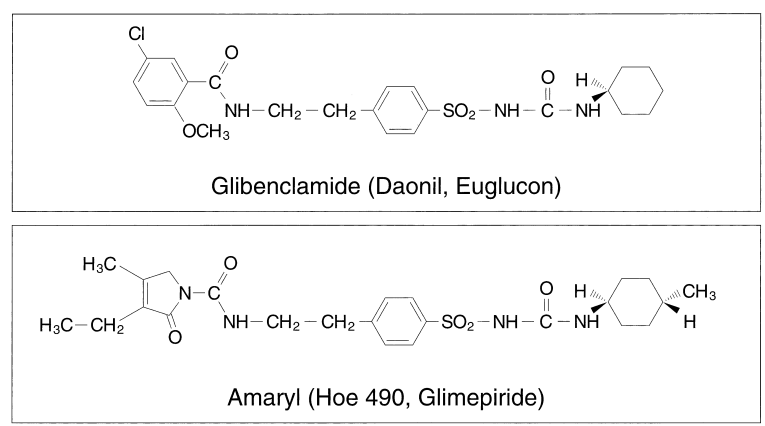

Fig. 1. Structures of Amaryl and glibenclamide. of peripheral tissues via distinct molecular mechanisms, compared with tolbutamide and glibenclamide. These differences may contribute to the unique pharmacological profile of Amaryl.

\section{Interaction of Amaryl with the Pancreatic $\beta$-cell}

It is now well established that increasing the closed probability of the $\beta$ cell ATP-dependent potassium channel $\left(\mathrm{K}_{\mathrm{ATP}}\right)$ is the major mechanism through which sulfonylureas, as well as glucose (via transport, phosphorylation, and oxidative metabolism for generation of ATP), stimulate insulin release from pancreatic $\beta$ cells (2). The resulting reduction in potassium ion efflux causes depolarization of the $\beta$-cell plasma membrane, which in turn leads to opening of voltage-sensitive $\mathrm{Ca}^{2+}$ channels of the L-type. The increased influx of $\mathrm{Ca}^{2+}$ and, thus, the elevated cytosolic $\mathrm{Ca}^{2+}$ levels trigger the fusion of insulin-containing secretory granules with the plasma membrane $(3,4)$. This is presumably mediated by $\mathrm{Ca}^{2+} /$ calmodulindependent protein kinase II (CaMKII). CaMKII is stimulated in the insulinoma cell line, MIN6, in response to secretagogues, such as glucose, the sulfonylurea tolbutamide and high $\mathrm{K}^{+}$, in parallel with insulin secretion (5) and phosphorylates proteins that are thought to be involved in the trafficking, docking, and fusion of insulin secretory granules (6). These include synapsin I, microtubule-associated protein-2 (MAP-2), Nethylmaleimide-sensitive fusion protein (NSF), soluble NSF attachment protein (SNAP), vesicleassociated membrane protein (VAMP/synaptobrevin), $\alpha$-SNAP, SNAP-25, and synaptotagmin (7) and additional unknown components that regulate the assembly/disassembly of the SNAP receptor (v/t-SNARE)/fusion protein complex. Interestingly, synapsin $\mathrm{Ib}$, the major isoform in MIN6 cells was found to be associated with some isoforms of the $\delta$-subunit of CaMKII in insulin secretory granules $(8,9)$. This may play a critical role in the regulation of the interaction between the granules and the cytoskeleton via CaMKII-dependent phosphorylation of synapsin I.

The $\beta$-cell $\mathrm{K}_{\mathrm{ATP}}$ consists of the regulatory sulfonylurea receptor subunits (SUR), such as SUR1, and the physically associated poreforming potassium ion inwardly rectifying subunit, KIR6.2, in a multimeric assembly 
with the SUR and KIR6.2 subunits in 1:1stoichiometry and four identical SUR/KIR6.2 complexes per functional channel unit [size of the channel holocomplex [SUR/KIR6.2 ${ }_{4}$ about $1000 \mathrm{kDa}(10-12)]$. SUR $\mathrm{l}$, which is predominantly expressed in glucose-responsive neurons of the hypothalamus and pancreatic $\beta$ cells, is an ATP-binding cassette (ABC) protein or transport ATPase, which closely resembles members of the multidrug resistance-associated protein family. It harbors 17 predicted transmembrane domains (TMD) and two nucleotidebinding folds (NBF), each constituted by a Walker motif A and B, which bind specifically $\left(\mathrm{Mg}^{2+}\right)$ ADP/ATP (Fig. 2) (13-15). The KIR6.2 subunits have two TMDs that somehow contribute to the $\mathrm{K}^{+}$conductivity and selectivity (16). The glibenclamide-binding site of SUR 1 is proposed to consist of a benzamido (meglitinide)-binding site on TMDs $1-5$ and the sulfonylurea (tolbutamide)-binding site on TMDs 12-17, based on photolabeling with $\left[{ }^{125} \mathrm{I}\right]$ iodoglibenclamide and chimeric receptors $(17,18)$. Interaction with both the meglitinideand tolbutamide-binding sites could account for the several thousand-fold increase in affinity of glibenclamide (equipped with both a benzamido and sulfonylurea moiety) vs. tolbutamide (equipped with a sulfonylurea moiety, only). SUR2A/B are splice variants of a single
SUR2 gene that exclusively differ in 42 amino acids at the carboxy-terminus, with SUR2A expressed mainly in cardiac/skeletal muscle cells and SUR2B in vascular/nonvascular smooth muscle cells (19). $\mathrm{K}^{+}$-channel openers (KCO) bind to SURs at the tolbutamide-binding site, encompassing those (flanking) TMDs 12-17 that surround the central core region of the tolbutamide-binding site (20). SURs define the sensitivity of the $\mathrm{K}_{\text {ATP }}$ holocomplex for its sensitivity toward both sulfonylureas and KCOs with SUR I mediating high sensitivity for sulfonylureas/low sensitivity toward KCOs and, vice versa, SUR2A/2B mediating low sensitivity for sulfonylureas/high sensitivity for KCOs. Chimeric SURs can be engineered by recombinant DNA technology (harboring TMDs 12-17 from both SUR 1 and SUR2A/B), with high sensitivity for both sulfonylureas and KCOs, arguing for a modular structural and functional organisation of SURs (20).

The cooperative interactions between NBFs 1 and 2 of SUR 1 in the open state of the $K_{\text {ATP }}$ are disrupted by the conformational change induced by glibenclamide-binding that encompasses TMD 12-17 and, especially, TMD 1-5 (Fig. 3) (18). This conformational change repositions TMD 2 of KIR6.2 (M2), which is in close contact to TMD 1-5 of SUR 1, to a closed state via a mechanism that requires the intact

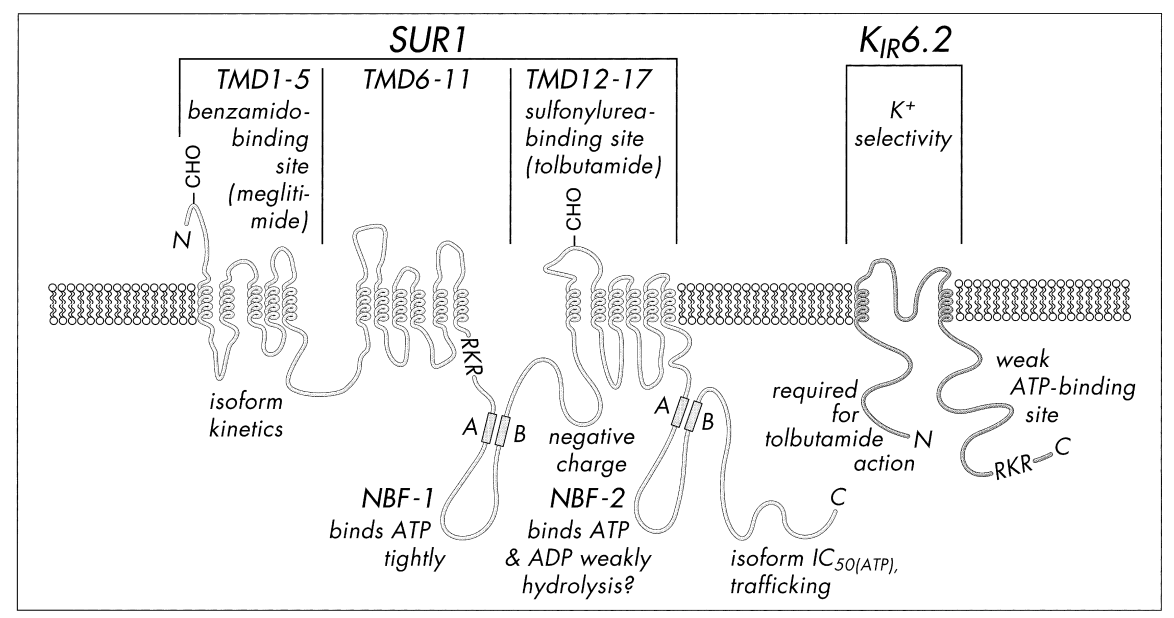

Fig. 2. Mapping of known properties of $K_{\text {ATP }}$ to segments and structural features of SUR and KIR6.2. [See text for details (18)]. The -RKR- motif has been demonstrated to function as quality control (protein trafficking) signal in keeping incompletely assembled $\mathrm{K}_{\mathrm{ATP}}$ (i.e. incorrect stoichiometry) from reaching the cell surface. This motif is found in the carboxy-terminus of subunit KIR6.2 and in sulfonylurea receptor protein for glibenclamide (SUR1) upstream of nucleotide-binding folds (NBF1), mutation of which leads to cell surface expression in the absence of the partner subunit (139). It may function as endoplasmic reticulum retention signal that is masked during assembly of the channel complex, thus, allowing only correctly assembled and functional (i.e. with regard to regulated conductivity) $K_{\text {ATP }}$ to reach the plasma membrane. CHO, putative glycosylation sites. TMD, transmembrane domains. 


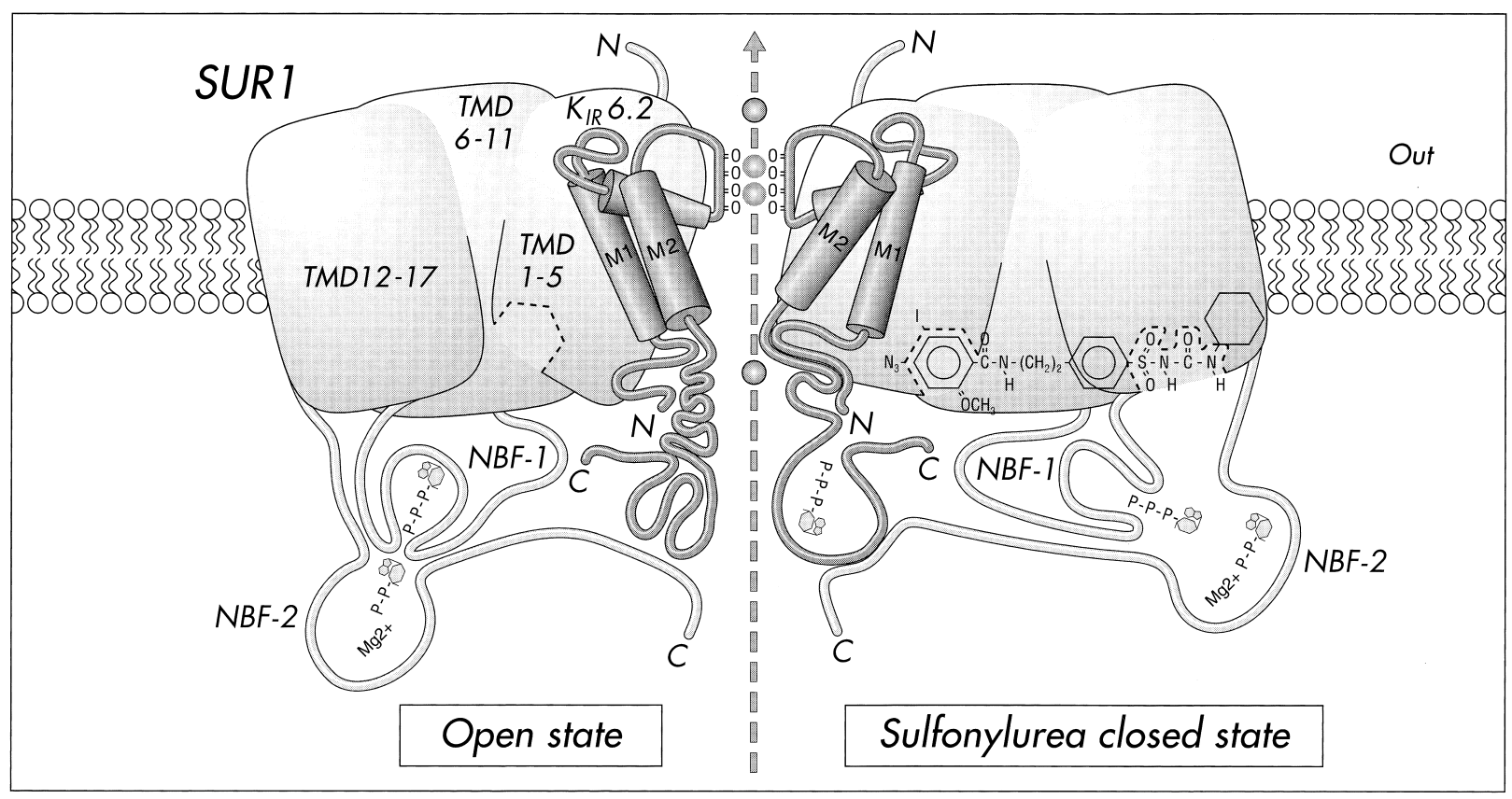

Fig. 3. Hypthetical model for the open and glibenclamide-induced closed states of a $\mathbf{K}_{\text {ATP. }}$ [See text for details (18)]. In the glibenclamidebound state (right section), interaction of the inhibitory ATP with subunit KIR6.2 is indicated; whereas, ATP and $\mathrm{Mg}^{2+}$ ADP (the interaction of

amino-terminus of KIR6.2. Thus, sulfonylureabinding to SURI apparently induces a subtle relaxation of the intimate association between SUR 1 and KIR6.2, which is required for keeping KIR6.2 in a (partly) open state. Compatible with this simplified view are recent findings that certain mutations in both SURl and KIR6.2 cause recessive forms of familial hyperinsulinism or persistent hyperinsulinemic hypoglycemia of infancy due to permanent closure of $\mathrm{K}_{\mathrm{ATP}}$, presumably in the course of weakening the interaction between SURI and KIR6.2 to a certain degree (21-23).

Binding of ATP to the carboxy-terminal domain of KIR6.2 facilitates and/or stabilizes the glibenclamide-induced relative dissociation of SUR1 and KIR6.2, possibly mediated by its proximity to the amino-terminus of KIR6.2, which is accomplished during repositioning of M2 (see above). Thereby, ATP-binding favours the closed state of the $\mathrm{K}_{\mathrm{ATP}}$. This may explain, in part, the (synergistic) stimulation of glucoseinduced (i.e. ATP-mediated) insulin release by sulfonylureas. In contrast, interaction of ATP with NBF-1 and $\mathrm{Mg}^{2+}$ ADP with NBF-2 of SUR 1 is relieved upon glibenclamide-binding (see Fig. 3), compatible with $\mathrm{Mg}^{2+}$ ADP-binding to which with the nucleotide-binding folds (NBFs) of sulfonylurea receptor protein for glibenclamide (SUR 1) in the open state is shown on the left section) are leaving NBF-1 and NBF-2, respectively, of SUR l. TMD, transmembrane domains.

NBF1/2 of SUR 1 triggering opening of KIR6.2. Site-directed mutations in a single NBF are sufficient to block the stimulatory effect of $\mathrm{Mg}^{2+}$ ADP. These mutations also prevent $\mathrm{K}_{\text {ATP }}$ activation by metabolic inhibition in intact cells $(24,25)$. This suggests an important role of SUR 1 and its NBFs, in particular, for metabolic regulation of the $K_{\text {ATP }}$ in response to low energy charge of the cell. Furthermore, mutations associated with persistent hyperinsulinemic hypoglycemia of infancy have been identified in SUR 1 that impair the ability of $\mathrm{Mg}^{2+}$ ADP to enhance $\mathrm{K}_{\mathrm{ATP}}$ channel activity, but do not change the inhibitory effect of ATP $(25,26)$. These mutations abolish the ability of KIR6.2 to respond to changes in the oxidative glucose metabolism and cause it to be permanently closed in the intact $\beta$ cell. These findings suggest that the physiological role of SUR 1 seems to rely on the mediation of metabolic regulation of channel activity in response to nutritional deprivation. The binding of sulfonylureas to SUR 1 may be simply providential.

Amaryl and glibenclamide bind to SURs of the $\beta$ cell with high specificity and affinity $(27,28)$. In kinetic experiments, the association and dissociation rate constants, $K_{\text {on }}$ and $K_{\text {off }}$ 
values, of Amaryl are 2.5- to 3-times and 8- to 9-times, respectively, higher than those of glibenclamide, using both membranes from solid New England Deaconess Hospital (NEDH) rat $\beta$-cell tumor or cultured rat insulinoma m5F (RINm5F) cells and intact cultured $\beta$-cells. The calculated 3- to 4-fold higher $\mathrm{K}_{\text {off }} / \mathrm{K}_{\text {on }}$-ratios of Amaryl, compared with glibenclamide, were identical to the dissociation constants $\left(\mathrm{K}_{\mathrm{d}}\right.$-values) as determined by Scatchard plot analysis under steady state conditions with all three sources of the receptors. The 3- to 4-fold lower binding affinity of Amaryl, compared with that of glibenclamide, was also reflected in homologous and heterologous competitions studies $(27,28)$. Three- to 4 -fold higher concentrations of unlabeled Amaryl, compared with glibenclamide, were required for half-maximal displacement of both radiolabeled Amaryl and glibenclamide from specific binding to membranes of cultured RINm5f cells. The lower binding affinity of Amaryl, compared with glibenclamide, correlates well to their depolarization activity (Fig. 4). In the presence of KCO (100 $\mu \mathrm{M}$ diazoxide), the inhibitory concentrations $\left(\mathrm{IC}_{50}\right)$ for depolarization of cultured RINm5F cells in the whole-cell patch-clamp configuration were 27.3 nM for Amaryl and $7.4 \mathrm{nM}$ for glibenclamide.

For elucidation of the molecular basis for the distinct binding and depolarisation characteristics of Amaryl, our lab performed direct photoaffinity labeling of $\beta$-cell membranes from diverse sources with unmodified radiolabeled Amaryl or glibenclamide $(29,30)$. As reported previously (31), $\left[{ }^{3} \mathrm{H}\right]$ glibenclamide was crosslinked to a $140-\mathrm{kDa}$ polypeptide, which corresponded to SUR I, and to an unidentified 33-kDa polypeptide. In contrast, a $65-\mathrm{kDa}$ polypeptide, SURX, exclusively was radiolabeled by $\left[{ }^{3} \mathrm{H}\right]$ Amaryl using both isolated $\beta$-cell tumor membranes and intact cultured $\beta$ cells for the photocrosslinking. Apparently, Amaryl and glibenclamide interacted with different sulfonylurea receptor proteins, SURs, of the $\beta$-cell plasma membrane. Surprisingly, an excess of unlabeled glibenclamide or tolbutamide included during the irradiation reaction completely inhibited photolabeling of SURX (65 kDa) by $\left[{ }^{3} \mathrm{H}\right]$ Amaryl and, vice versa, unlabeled Amaryl reduced photolabeling of SURI (140 kDa) by $\left[{ }^{3} \mathrm{H}\right]$ glibenclamide in a concentration-dependent fashion with similar efficiacy as glibenclamide (29). Thus, SURI and SURX seem to interact with one another in a cooperative fashion.

Using similar techniques, it has been demonstrated in earlier studies that glibenclamide, in addition to specific binding to the $140-\mathrm{kDa}$ protein, specifically interacts with about 40 - and $65-\mathrm{kDa}$ polypeptides $(32,33)$. Thus, it cannot be excluded that glibenclamide also binds to SURX, albeit with significantly lower affinity than Amaryl. Alternatively, different ligands, such as Amaryl and glibenclamide, may recognize SURX in different conformational states, which would affect the binding affinity and selectivity of either Amaryl or glibenclamide. This would explain the distinct patterns of photoaffinity labeling and equilibrium/kinetic binding. Nevertheless, on

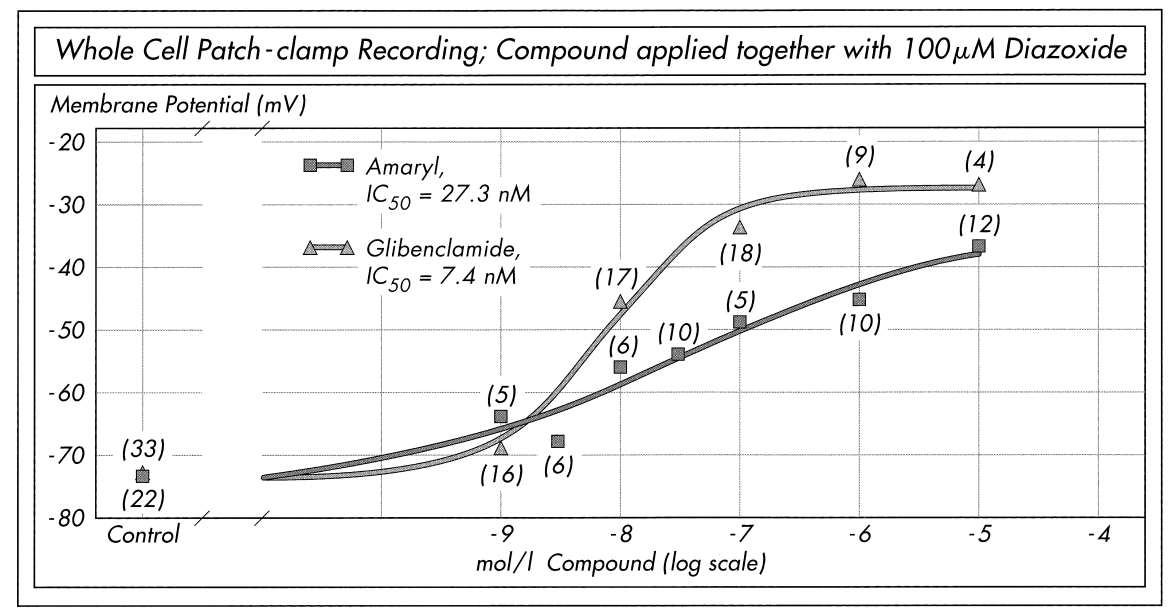

Fig. 4. Effect of Amaryl and glibenclamide on the diazoxide-activated membrane potential of cultured rat insulinoma m5F (RINm5F) cells. The numbers of measurements at each concentration are indicated. IC $_{50}$, inhibitory concentrations. 
basis of the (I) unambigous photolabeling of SUR 1 by glibenclamide, but not Amaryl under the same experimental conditions and (II) considerably different (albeit overlapping) binding characteristics of the two drugs, different SURs, i.e. SURI and SURX, may be proposed as the major specific binding proteins for glibenclamide and Amaryl, respectively, in the $\beta$ cell.

These data and considerations together suggest the following structural model for the $\beta$-cell $\mathrm{K}_{\text {ATP. }}$. Conventional sulfonylureas, such as glibenclamide, and the novel sulfonylurea, Amaryl, bind to distinct receptor subunits, the well-characterized SUR I, and SURX (identified so far by photoaffinity labeling only), respectively. SURI and SURX interact with each other in a cooperative fashion and control the open/closed probability of the associated pore-forming subunits, KIR6.2, SURl independent of SURX, and SURX in close coupling to SURI only. In the putative functional 12meric channel complex consisting of four identical SUR 1/SURX/KIR6.2 trimers, (SUR l/ SURX/KIR6.2) $)_{4}$, and embedded in the intact $\beta$-cell membrane, Amaryl and glibenclamide manage to bind to and photolabel SURX and SUR 1, respectively; whereas, upon membrane solubilisation by detergents and concomitant complex dissociation, both Amaryl and glibenclamide interact with SURX, exclusively (29).

\section{The Insulin-independent Blood Glucose-Decreasing Activity of Amaryl in Animals}

Despite the lower $\beta$-cell activity of Amaryl vs. glibenclamide in terms of binding affinity and duration of binding, as well as depolarization, clinical studies reveal a higher blood glucoselowering activity of Amaryl in man, because the doses required for equivalent blood glucose decreases are $50-70 \%$ of those of glibenclamide (Fig. 5) (34-38). This is in striking contrast to the conventional view that the blood glucose-decreasing activity of sulfonylureas is based solely on the stimulation of insulin release from the pancreatic $\beta$ cell. Since the introduction of sulfonylureas into the therapy of NIDDM, a controversial debate has emerged as to whether these oral hypoglycemic drugs, in addition to their capacity for inducing insulin release, have an insulin-independent blood glucose-decreasing activity, such as an activity that does not require additional insulin release.

\begin{tabular}{|c|c|c|}
\hline \multicolumn{1}{|c|}{} & Amaryl & Glibenclamide \\
\hline Binding affinity & 1 & $3-4$ \\
\hline Duration & 1 & $2.5-3.5$ \\
\hline Depolarization Potency & 1 & $3-3.5$ \\
\hline \begin{tabular}{l}
\hline nevertheless \\
Dose for equivalent \\
blood glucose \\
decrease in humans
\end{tabular} & $1 / 3-1 / 2$ & \\
\hline
\end{tabular}

Fig. 5. Comparison of Amaryl and glibenclamide for efficiacy at the $\beta$ cell $\mathrm{K}_{\mathrm{ATP}}$ and hypoglycemic activity. The $K_{d}(6.8 \mathrm{nM})$ and association rate constant, $\mathrm{K}_{\text {on }}\left(0.5 \mathrm{~min}^{-1} / \mathrm{nM}^{-1}\right)$, values for binding and the inhibitory concentrations $\left(\mathrm{IC}_{50}\right)$ for depolarization $(27.3 \mathrm{nM})$

determined for membranes of cultured rat insulinoma m5F (RINm5F) cells or intact cells, respectively, were set at 1 for Amaryl, the dose required for equivalent blood glucose decrease in humans was set at 1 for glibenclamide.

The observation that after chronic treatment of NIDDM patients with sulfonylureas, their plasma insulin levels return to near pretreatment levels without concomitant loss of hypoglycemic control has been explained by insulin-independent activities of these drugs exerted at both pancreatic and extrapancreatic tissues (1).

To re-evaluate the possibility of an insulinindependent blood glucose-decreasing activity of sulfonylureas, in general, and of Amaryl, in particular, we reason that the ratio of the sulfonylurea-induced mean plasma insulin release and mean blood glucose decrease measured over the total study period should be identical for structurally different sulfonylureas, provided the time response curves for the insulin release and blood glucose decrease exhibit similar shapes and the blood glucose decrease is based solely on the stimulation of insulin release. Different ratios for structurally different sulfonylureas would argue in favour of the operation of an additional insulinindependent blood glucose-decreasing activity. To test this hypothesis, in four different experiments, Amaryl and the sulfonylureas, glibenclamide, gliclazide and glipizide, were tested in normal fasted beagle dogs at submaximal single oral or i.v. doses, which lower blood glucose nadir levels to about the same degree for their blood glucose-lowering and plasma insulin-releasing activity $(39,40)$. For instance, after single oral administration of different doses of these sulfonylureas, Amaryl $(90 \mu \mathrm{g} / \mathrm{kg})$ 
had the highest total blood glucose-lowering activity and the lowest insulin-releasing activity during the $36 \mathrm{hr}$ post-treatment period; whereas, glipizide $(180 \mu \mathrm{g} / \mathrm{kg})$ had the lowest total blood glucose-lowering activity, and highest insulin-releasing activity, and glibenclamide $(90 \mu \mathrm{g} / \mathrm{kg})$ and gliclazide $(1.8 \mathrm{mg} / \mathrm{kg})$ ranked between the two extremes. For calculation of the plasma insulin/blood glucose ratio by means of the trapezoidal rule for each animal, the mean plasma insulin increase and mean percentage blood glucose decrease over the whole study period in fasted male beagle dogs after a single oral or i.v. dose of the different sulfonylureas were determined. Singledose studies over periods of $0-8 \mathrm{hr}$ to up to 0-51 hr were preferred to exclude possible indirect effects of prolonged sulfonylurea treatment secondary to the decreased basal blood glucose and plasma insulin levels via improvement of the metabolic overall situation and/or insulin sensitivity.

In these studies, the shapes of the blood glucose and plasma insulin curves and the blood glucose nadirs were approximately identical. However, for a given experiment, the ratios differed for different sulfonylureas (e.g. Amaryl, 0.03; gliclazide, 0.07; glipizide, 0.11; and glibenclamide, 0.16). Within each experiment there was an identical ranking of the ratios of the mean plasma insulin release/ mean blood glucose decrease among the various sulfonylureas. Amaryl exhibited the lowest ratio in each experiment. This was due primarily to a statistically significant lower plasma insulin release (with respect to both maximal and mean plasma insulin levels) in response to Amaryl, compared with the other drugs (e.g. mean plasma insulin levels: Amaryl, $0.6 \mu \mathrm{U} / \mathrm{ml}$; gliclazide, 1.3; glipizide, 1.6; and glibenclamide, 3.3). The differences and the ranking in the plasma insulin/blood glucose ratios suggest that sulfonylureas have insulinindependent blood glucose-decreasing activity and that this is more pronounced for Amaryl than for conventional sulfonylureas.

This interpretation could be strengthened by a number of additional animal experiments, the results of which are not compatible with insulin release as the only mechanism for sulfonylurea-induced blood glucose decrease $(39,40)$. (I) Administration of higher single oral and i.v. doses $(60 \mu \mathrm{g} / \mathrm{kg})$ to normal fasted rabbits provoked approximately identical time response curves for the blood glucose decrease up to $8 \mathrm{hr}$ for Amaryl and glibenclamide. However, during the following $40 \mathrm{hr}$, the Amaryl animals showed significantly lower blood glucose levels; thus, apparently, Amaryl had the longer-lasting blood glucose-decreasing activity. Remarkably, at these later time points after both i.v. or oral administration (20-48 hr), there was still a pronounced blood glucose decrease induced by Amaryl and the plasma insulin levels of the Amaryl animals already had decreased to near basal levels. (II) In normal fasted beagle dogs treated with a single oral dose of $90 \mu \mathrm{g} / \mathrm{kg}$ of Amaryl or glibenclamide and, subsequently (30 min later), repeatedly loaded orally with glucose $(2 \mathrm{~g} / \mathrm{kg})$ in $5 \mathrm{hr}$ intervals for up to $50 \mathrm{hr}$, the mean blood glucose concentrations over the whole study period in the Amaryl and glibenclamide animals were significantly lower than those in the controls. However, the mean plasma insulin values also were lower in both drug groups, with the Amaryl animals exhibiting significantly lower mean plasma insulin levels than the glibenclamide animals. (III) In manifestly diabetic KK- $\mathrm{A}^{\mathrm{Y}}$ mice, a typical type II diabetes animal model, Amaryl $(0.5 \mathrm{mg} / \mathrm{kg} /$ day $)$ reduced the blood glucose and plasma insulin levels by $50 \%$ and the glycated hemoglobin $\left(\mathrm{HBA}_{1 \mathrm{C}}\right)$ by $33 \%$ after 8 weeks of once-daily treatment. Glibenclamide $(1.25 \mathrm{mg} / \mathrm{kg} /$ day $)$ and gliclazide $(20 \mathrm{mg} / \mathrm{kg} /$ day $)$, at equipotent blood glucose-decreasing doses in rabbits, had no effect on blood glucose, plasma insulin, and $\mathrm{HBA}_{1 \mathrm{C}}$ under these experimental conditions.

The described pharmacological data can only be explained by the assumption that an insulin-independent blood glucose-decreasing activity operates at the level of pancreatic and/or extrapancreatic tissues during sulfonylurea action, in general, and Amaryl action, in particular. Possible mechanisms include inhibition of glucagon release from pancreatic $\alpha$ cells, interference with insulin removal by the liver, facilitation of transendothelial transport of insulin, increase of insulin sensitivity in peripheral tissues, and direct stimulation of glucose utilization in muscle and fat tissues. There is some experimental evidence that sulfonylureas may affect all these processes to some extent, e.g. attentuation of glucagon secretion by Amaryl (41). However, a number of in vitro studies with isolated and cultured insulin-sensitive fat and muscle cells that used well-defined incubation conditions in the presence of Amaryl and/or glibenclamide have 
been performed during the last decade (42-50). Most data argue for an improvement of insulin sensitivity and an increase of glucose utilization in peripheral tissues as the major potential mechanisms for blood glucose decrease by sulfonylureas, in addition to insulin release (42-50). In vivo, these mechanisms will lead to increased glucose flux from the blood into muscle and fat tissues, even in the absence of (additional) insulin. Therefore, the following part of the review is dedicated to the underlying molecular basis. As a prerequisite for the in vivo relevance of a mechanism identified in vitro, the ranking of the potency ratios [determined as the ratio of equi-effective concentrations of the two drugs derived from the respective graded (by parallel line assay) concentration-response relations] between different sulfonylureas calculated from the in vitro data should correspond to that of their insulin release/blood glucose decrease ratios in vivo.

\section{Direct Stimulation of Glucose Utilization by Amaryl in Fat and Muscle Cells In Vitro}

The major pathway for rapid glucose utilization is the non-oxidative glucose metabolism with the two branches of glycogen and lipid synthesis. Therefore, the effects of Amaryl and glibenclamide on glycogenesis and lipogenesis in the isolated rat diaphragm and cultured mouse 3 T3 adipocytes, respectively, were studied (42). Both drugs concentration-dependently stimulated glycogenesis up to 2.5-fold and lipogenesis to up to 4.2 -fold (at $20 \mu \mathrm{M}$ ) above basal after $4 \mathrm{hr}$ and $20 \mathrm{hr}$ incubation, respectively. The maximal responses (synthesis rates) did not differ between Amaryl and glibenclamide. But, there was a statistically significant leftwardshift of the concentration-response curves for Amaryl, compared with those for glibenclamide. This resulted in about $50 \%$ reductions of the corresponding effective concentrations $\left(\mathrm{EC}_{50}\right)$, which were in the 1 to $5 \mu \mathrm{M}$ range. At low glucose concentrations, the rate of lipogenesis and glycogenesis in vivo is controlled by the glucose transport step. Both drugs stimulated concentration-dependently the transport of the nonmetabolizable glucose analog, 2-deoxyglucose, into 3T3 adipocytes up to 6.8 -fold (at $20 \mu \mathrm{M}$ ) and in rat diaphragms up to 1.8-fold (at $20 \mu \mathrm{M}$ ) (42). Again, Amaryl and glibenclamide showed the same maximal responses, but with a potency ratio of 2.4 and 1.8, respectively, in favour of Amaryl.

NIDDM is related causally to resistance of the glucose transport system for stimulation by insulin. This insulin-resistant state can be mimicked in vitro by preincubation of isolated rat adipocytes with high concentrations of insulin, glutamine, and glucose in primary culture. This mimicks the diabetic milieu to which tissues are exposed during the pathogenesis of NIDDM. When these cells were assayed subsequently for insulin sensitivity in low glucosecontaining medium, the maximal insulinstimulated glucose transport (at $10 \mathrm{nM}$ ) was reduced by about $60 \%$ and the $\mathrm{EC}_{50}$ for insulin was increased 3- to 3.5-fold, compared with control cells (51). In contrast, the maximal response (at $10 \mu \mathrm{M}$ ) and the $\mathrm{EC}_{50}$ for Amaryl hardly were affected by the insulin-resistant state, resulting in concentration-response curves that were virtually identical for normal and insulin-resistant adipocytes. Apparently, Amaryl activates the glucose transport system in (insulin-resistant) isolated rat adipocytes by interference at a site downstream of the putative insulin resistance defect. Insulin stimulates glucose transport in fat and muscle cells by increasing the cell surface expression of the glucose transporter isoforms, GLUT4, and to a minor degree, GLUT1 (52). Upon insulin binding, the autophosphorylated insulin receptor activates the downstream signaling cascade, which via a complex network of phosphorylations of signaling molecules and metabolic enzymes, as well as interactions between them, induces lipid and glycogen synthesis and triggers the fusion of intracellular GLUTcontaining vesicles with the plasma membrane, the so-called GLUT4/1 translocation $(53,54)$. After incubation of normal isolated rat adipocytes for $20 \mathrm{~min}$ with $10 \mathrm{nM}$ insulin, the amount of GLUT4 at the plasma membrane was raised 6.5- to 7.5-fold, accompanied by a corresponding decrease of GLUT4 in intracellular vesicles (51). In insulin-resistant adipocytes, the insulin-stimulated GLUT4 translocation was reduced 1.8- to 2.2-fold. Amaryl, however, stimulated GLUT4 translocation up to 2.5- to 3.0-fold in both normal and insulin-resistant adipocytes. Similarly, the (less pronounced) GLUT1 translocation was reduced considerably in insulin-resistant adipocytes, compared with normal adipocytes in response to insulin, but not Amaryl (51). Thus, GLUT translocation is 
part of the molecular basis for the efficient glucose transport stimulation by Amaryl in both normal and insulin-resistant cells.

\section{Regulation of Key Metabolic Proteins/Enzymes by Amaryl in Adipose Cells}

Phosphorylation of GLUT4 is one potential mechanism for regulation of the distribution of GLUT4 between the plasma membrane and the intracellular GLUT4 vesicles. This is compatible with our finding that, after induction of insulin resistance in isolated rat adipocytes, the phosphorylation state of GLUT4 was significantly increased, compared with that of normal cells (51). Treatment of insulin-resistant adipocytes with insulin (10 $\mathrm{nM}$ for $20 \mathrm{~min}$ ) reduced the amount of phosphorylated GLUT4 by $30-40 \%$, and treatment with Amaryl $(10 \mu \mathrm{M})$, by $70-80 \%$. Since GLUT4 is already in the phosphorylated state after full desensitization of the adipocytes, Amaryl obviously activates a (presumably serine-/ threonine-specific) protein phosphatase dephosphorylating GLUT4, rather than inhibits a GLUT4specific protein kinase. The dephosphorylation may reduce the internalization rate of GLUT4. The impaired internalization, in conjunction with the constitutive externalization of GLUT4 even in the absence of insulin, as was demonstrated for adipocytes (53), ultimately will lead to a net flux of GLUT4 molecules from the intracellular GLUT4 vesicles to the plasma membrane. The Amaryl-induced GLUT4 dephosphorylation and, in consequence, translocation may be particularly prominent in insulin-resistant adipocytes, due to their high content of phosphorylated GLUT4 (51). In addition to this dephosphorylation mechanism as the molecular basis for Amaryl-induced GLUT translocation, studies with isolated rat cardiomyocytes demonstrated the induction of GLUT1 and GLUT4 expression by Amaryl (55). The total amount of GLUT1 and 4 protein increased 1.7- and 1.5fold, respectively, in response to $20 \mathrm{hr}$ incubation with $10 \mu \mathrm{M}$ Amaryl. This correlates well with the approximate 2-fold increase in basal, as well as insulin-stimulated 2-deoxyglucose transport. Apparently, in cardiomyocytes, the Amaryl-induced GLUT1/4 gene/protein expression is the molecular basis for direct (insulinmimetic) stimulation, as well as potentiation of the insulin stimulation of GLUT 1/4 translocation and glucose transport by this drug (56).
At high glucose concentrations, such as in the diabetic state, glycogen synthase (GS) and glycerol-3-phosphate acyltransferase (GPAT) are rate-limiting for glycogenesis and lipogenesis, respectively, rather than glucose transport. Both enzymes are stimulated by Amaryl and glibenclamide in a concentration-dependent fashion (42). GS activity increased up to 5.5fold (at $20 \mu \mathrm{M}$ ) after $4 \mathrm{hr}$ incubation in the isolated rat diaphragm; GPAT activity up to 1.9fold (at $20 \mu \mathrm{M}$ ) after $20 \mathrm{hr}$ incubation in $3 \mathrm{~T} 3$ adipocytes. The potency ratios of 3.5 and 1.9, respectively, are in favour of Amaryl. Both enzymes are known to be inhibited by phosphorylation by cAMP-dependent protein kinase A (PKA). Amaryl stimulated the particulate (microsomal) cAMP-specific cGMP-inhibitable phosphodiesterase (presumably PDE3B) in a concentration-dependent fashion up to 2.3-fold (at $10 \mu \mathrm{M}$ ) in isolated rat adipocytes, thus lowering cytosolic cAMP levels. Furthermore, Amaryl reduced cytosolic PKA activity by up to $30 \%$ (at $20 \mu \mathrm{M}$ ), even in the presence of excess of cAMP, and thus in a CAMP-independent manner (42). For both effects, which ultimately will lead to reduced cAMP-dependent phosphorylation of GS and GPAT and, in consequence to their activation, the potency ratios were in slight favour of Amaryl, compared with glibenclamide.

In addition to the inhibition of cAMPdependent phosphorylation, evidence was found for the activation of protein phosphatases partly mediating the stimulatory effects of sulfonylureas on glycogenesis and lipogenesis (Fig. 6). Activation of GS and GPAT by Amaryl in isolated rat diaphragms and adipocytes, respectively, was blocked completely in the presence of the serine-/ threonine-specific protein phosphatase inhibitor, okadaic acid (100 nM). The proposed Amaryl-induced dephosphorylation of key metabolic enzymes of glucose and lipid metabolism was demonstrated directly for GS in isolated rat adipocytes. Amaryl caused a significant concentration-dependent reduction in the phosphorylation of GS, which was more potent compared with that provoked by glibenclamide. Insulin also lowered the phosphorylation state of GS and was most effective. In addition to PKA, glycogen synthase kinase 3 (GSK-3) phosphorylates and, thereby, inhibits GS. Compatible with the involvement of GSK3, we found that GSK-3 activity (measured as autophosphorylation) was down-regulated in 


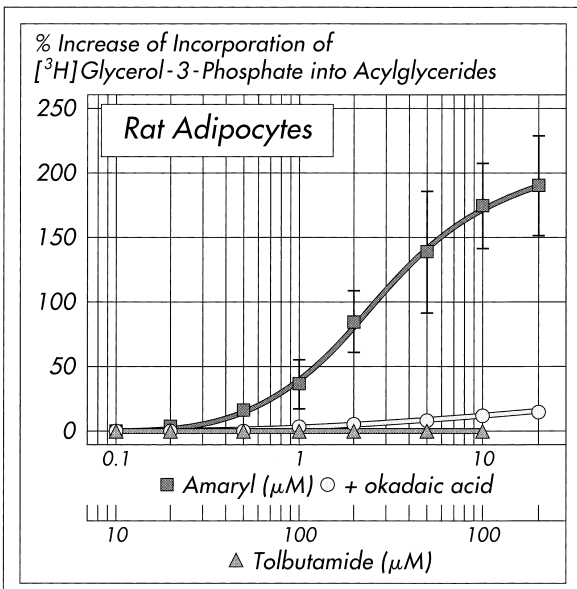

Fig. 6. Effect of okadaic acid on the activation of key metabolic enzymes by Amaryl in rat adipocytes and diaphragms. Isolated rat adipocytes or diaphragms were treated with $100 \mathrm{nM}$ okadaic acid for $5 \mathrm{~min}$ at $30^{\circ} \mathrm{C}$ prior to incubation with increasing concentrations of Amaryl or tolbutamide for $30 \mathrm{~min}$. For determination of glycerol-3-phosphate acyltransferase (GPAT) activity, total microsomes isolated from the cell homogenates were incubated with $\left[{ }^{3} \mathrm{H}\right]$ glycerol3-phosphate for $3 \mathrm{~min}$ at $25^{\circ} \mathrm{C}$. For determination of glycogen synthase (GS) activity, a

response to both the sulfonylureas, Amaryl and glibenclamide, and insulin in isolated rat adipocytes. Tolbutamide failed to significantly diminish both GS phosphorylation and GSK-3 autophosphorylation. GSK-3 is a key regulatory enzyme of glycogen metabolism and, in addition, a key signaling component of the insulin signal transduction cascade located downstream, presumably at the site of signal divergence to the metabolic and mitogenic pathways (57).

\section{Insulin-mimetic Signaling of Amaryl in Adipose Cells}

The demonstrated stimulatory effects of Amaryl on nonoxidative glucose metabolism (i.e. glucose transport, GLUT4 translocation, lipid and glycogen synthesis, GPAT and GS activity) and dephosphorylation, resemble the pleiotropic metabolic insulin actions that are mediated by the insulin signal transduction cascade (57). The insulin signal generated by insulin receptor kinase-mediated tyrosine phosphorylation of the insulin receptor substrate (IRS) proteins (58) is thought to diverge to the various termi-

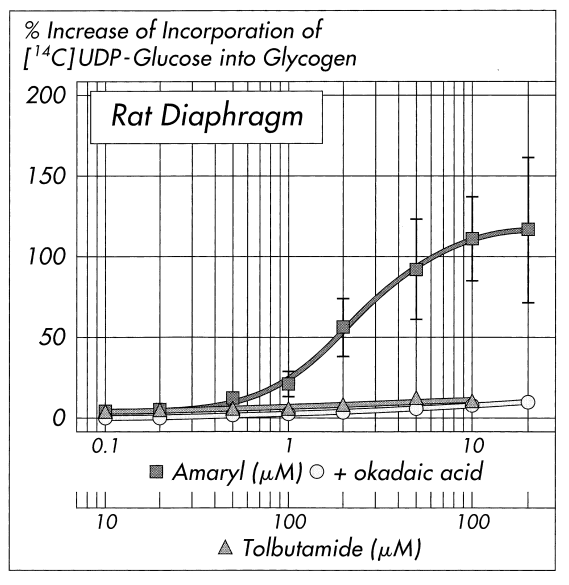

post-mitochondrial supernatant prepared from the cell homogenates was incubated with $\left[{ }^{14} \mathrm{C}\right]$ UDPglucose for $10 \mathrm{~min}$ at $30^{\circ} \mathrm{C}$. The activities were calculated from the radiolabeled acylglycerides in the butanol phase for GPAT and radiolabeled glycogen in the ethanol precipitate for GS as described previously $(42,136)$. The specific activity (difference between presence and absence of enzyme source) in the absence of drug was set at $0 \%$ in each case. Each point represents the means \pm standard deviation (SD) of (at least) three independent experiments.

nal metabolic effector systems, such as GLUT4, GPAT, and GS, at sites downstream of phosphatidylinositol-3-kinase (PI-3K), protein kinase B (PKB), and GSK-3 (59). Therefore, we studied a possible interference of Amaryl with insulin signaling components located upstream of GSK-3.

GSK-3 is phosphorylated and, thereby, inhibited by PKB. In isolated rat adipocytes, Amaryl and, to a minor degree, glibenclamide, but not tolbutamide, stimulated in a concentration-dependent fashion PKB activity up to 3.6and 2.3-fold, respectively (at $20 \mu \mathrm{M}$; G. Müller, S. Welte, N. Hanekop, manuscript submitted). PKB is phosphorylated (by phosphoinositidedependent kinases 1 and 2) and, thereby, activated in response to active PI-3K $(60,61)$. PI-3K activity was increased in a concentrationdependent fashion in response to glibenclamide and, more potently, Amaryl up to 3.1- and 4.4fold (at $20 \mu \mathrm{M}$ ), respectively. During insulin action, PI-3K becomes activated by binding to tyrosine-phosphorylated IRS proteins $(62,63)$. Interestingly, in rat adipocytes, Amaryl caused concentration-dependent tyrosine phosphorylation of IRS- 1 and 2, and association of PI-3K with IRS-1 and 2. Tyrosine phosphorylation of 
IRS- 1 and 2 and their association with p85 of PI-3K were more pronounced with Amaryl (EC ${ }_{50}$ about $\left.3 \mu \mathrm{M}\right)$, compared with glibenclamide; whereas, tolbutamide was ineffective (G. Müller, S. Welte, N. Hanekop, manuscript submitted). The principle IRS involved in metabolic regulation are IRS- 1 and IRS-2, and there is abundant biochemical evidence to support this view $(62,64)$. Genetic evidence from animals devoid of IRS-1 $(65,66)$ and IRS-2 $(67)$ further suggests that these molecules are intimately involved with the signaling to metabolic pathways regulated by insulin. Two additional members of the IRS family, IRS-3 and IRS-4, have been described, but they are unlikely to be involved in insulin-dependent metabolic regulation, because the latter is not expressed in the appropriate tissues (68) and a knockout of the former has no obvious metabolic phenotype (69). IRS- 1 and 2 contain numerous tyrosine residues that, when phosphorylated, act as docking sites for a certain set of Src homology 2 domain-containing proteins. In particular, it is the activation of PI-3K in association with tyrosine-phosphorylated IRS- 1 and 2 that propagates the insulin signaling cascade required for most or all of insulin's pleiotropic actions, including metabolic regulation.

Insulin provokes tyrosine phosphorylation of IRS proteins by activation of the insulin receptor tyrosine kinase $\beta$-subunit $(57,64)$. In contrast, Amaryl has no direct effect on the insulin receptor. Takada and coworkers (70) did not find any significant effect of Amaryl on the number and binding affinity of skeletal muscle insulin receptor in genetically diabetic $\mathrm{KK}-\mathrm{A}^{\mathrm{y}}$ mice as well as on autophosphorylation of the human insulin receptor heterologously expressed in rat fibroblasts. This raises the question of how Amaryl manages to induce tyrosine phosphorylation of the IRS proteins in adipose and muscle cells. Interestingly, we identified another protein, caveolin, which became tyrosine-phosphorylated in isolated rat adipocytes in response to concentrations of Amaryl that were effective for stimulating glucose transport (40). Tyrosine phosphorylation of this $29-\mathrm{kDa}$ plasma membrane protein was increased up to 4.2 -fold above basal (at $5 \mu \mathrm{M}$ ). Remarkably, treatment of intact rat adipocytes with insulin or a bacterial phosphatidylinositol (PI)-specific phospholipase C (PLC) also caused tyrosine phosphorylation of caveolin up to 9.2- (at $2 \mathrm{nM}$ ) and 2.1-fold (at $10 \mu \mathrm{U} / \mathrm{ml}$ ), respectively $(40)$.
The PI-PLC cleaves glycosyl-phosphatidylinositol (GPI) lipids. They exist either in free form or as membrane anchors covalently bound to GPI-anchored proteins (GPI proteins). GPI proteins are cell surface ectoproteins of eucaryotic cells and embedded in the outer leaflet of the plasma membrane by the covalently linked GPI moiety (71), such as the cAMP-binding ectoprotein, Gcel, of rat and mouse adipocytes $(72,73)$. Many cell types, including adipose and muscle cells, harbor an endogenous GPI-specific PLC (GPI-PLC) that, upon activation, causes the release of the protein moiety of GPI proteins from the cell surface into the cellular environment due to lipolytic cleavage of its GPI anchor $(74,75)$. In isolated and cultured adipocytes, certain GPI proteins, such as lipoprotein lipase (72), are released from the cell surface into the incubation medium by the action of an endogeneous GPIPLC that is activated by both insulin (74-77) and Amaryl $(73,76,77)$. In normal rat adipocytes, Amaryl activated the GPI-PLC concentrationdependently by up to $30 \%$ of the maximal insulin effect $(3 \mu \mathrm{M})$ after $4 \mathrm{hr}$ incubation. In insulin-resistant adipocytes, stimulation of the enzyme by insulin was reduced drastically (by 55-65\%, compared with normal cells); whereas, activation by Amaryl was not diminished significantly (76). In contrast to the insulin effect, which required 15 min only, for full stimulation up to 14.5-fold above basal (at $10 \mathrm{nM}$ ), activation of the GPI-PLC by Amaryl in vitro was dependent strictly on the incubation time with a maximum of up to 9-fold (at $5 \mu \mathrm{M}$ ) after $4 \mathrm{hr}$ as demonstrated in rat adipocytes for the cleavage of the GPI anchor of Gcel (conversion of the uncleaved amphiphilic to the lipolytically cleaved hydrophilic version; Fig. 7). Tolbutamide, at 100-fold higher concentrations, was completely ineffective even after $4 \mathrm{hr}$ incubation.

\section{Interaction of Amaryl with Caveolae/DIGs}

Caveolin is tyrosine-phosphorylated in response to Amaryl. GPI-PLC is activated in response to Amaryl. GPI lipids/proteins are cleaved lipolytically in response to Amaryl. All of these elements are not equally distributed over the cell surface. Rather, they appear to be clustered together with another marker protein, flottilin, and other glycolipids, glycosphingolipids, cholesterol, and lipid-modified signaling proteins (such as heterotrimeric and small G-proteins, 


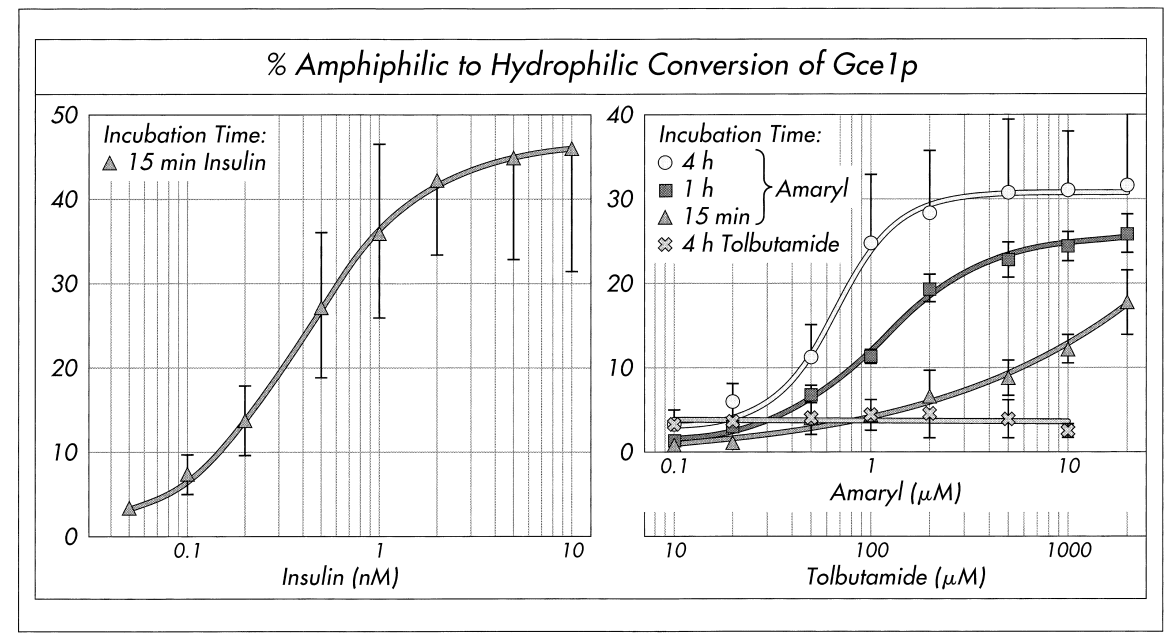

Fig. 7. Time-dependent activation of the glycosyl-phosphatidylinositol-phospholipase C (GPI-PLC) by Amaryl and insulin in rat adipocytes. Isolated rat adipocytes were photoaffinity-labeled with $\mathrm{N}_{3}-\left[{ }^{32} \mathrm{P}\right]$ CAMP $(72,73)$ and then incubated with increasing concentrations of different sulfonylureas or human insulin for the periods indicated at $30^{\circ} \mathrm{C}$. Plasma membranes were prepared by differential centrifugation and then

acylated non-receptor tyrosine kinases, protein kinase $\mathrm{C}$ isoform $\alpha$, and certain receptors and transporters) in special areas of the plasma membrane, the so-called caveolae (78). Caveolae are small bulb-/flask-shaped invaginations of the plasma membrane present in most cell types, but highly abundant in terminally differentiated cells such, as adipocytes $(20 \%$ of the total plasma membrane surface area), myocytes, epithelial, and endothelial cells. These subcompartments or microdomains of the plasma membrane are assumed to play important functions in cellular transport processes (transcytosis, potocytosis, endocytosis, and cholesterol flux) and transmembrane signal transduction ("caveolae signaling hypothesis") (79). Morphological appearance of caveolae directly correlates with caveolin expression. Caveolin is expressed in tissue-specific manner with three isoforms (caveolin 1, 2 and 3; see Fig. 8) and two different translation initiation sites (caveolin $1 \alpha$ and $1 \beta)(80-82)$. It functions as a marker, coat and scaffolding protein, based on its capacity to form homo-oligomers and to self-associate into precursor-like "pre-caveolae". The functional domains were defined recently (Fig. 8) (81-84). The biochemical correlate of caveolae can be isolated as so-called detergentinsoluble glycolipid-enriched rafts (DIGs), since they resist solubilization by $1 \% \mathrm{TX}-100$ subjected to partitioning between an aqueous and a TX-114 phase. Both phases were measured for radioactivity by liquid scintillation counting. The radioactivity contained in the TX-114 phase due to the presence of the uncleaved amphiphilic version of the GPI protein, Gcel, at time point 0 in the absence of agent was set at $100 \%$. Each point represents the mean \pm standard deviation (SD) of (at least) four independent experiments.

in the cold and are characterized by a low buoyant density, due to their high content of lipids (85). Actually DIGs may correspond to "pre-caveolae" (86).

The putative involvement of caveolin, the GPI-PLC, and GPI lipids/proteins in Amaryl action in adipocytes and their localization in caveolae/DIGs raises the possibility of a direct interaction of Amaryl with these components. Therefore, we studied the putative association of authentic radiolabeled Amaryl with adipocyte membrane fractions by direct photoaffinity labeling (40). Significant photocrosslinking of $\left[{ }^{3} \mathrm{H}\right]$ Amaryl to polypeptides of an apparent size beween 5 and $250 \mathrm{kDa}$ was not observed. Radiolabeled Amaryl was found covalently bound predominantly to two lipid species of similar migration behaviour (during thin layer chromatography), which were recovered predominantly with DIGs. Low or minute amounts of Amaryl, only, were found associated with lipids from plasma membranes and microsomes. A direct interaction of Amaryl with glycolipids residing in DIGs was suggested by two-dimensional thin layer chromatographic analysis of the photoaffinitylabeled lipids. The migration behaviour of the major Amaryl-labeled material was similar to, but not identical with, free GPI lipids prepared from yeast (40). Preliminary data demonstrated 


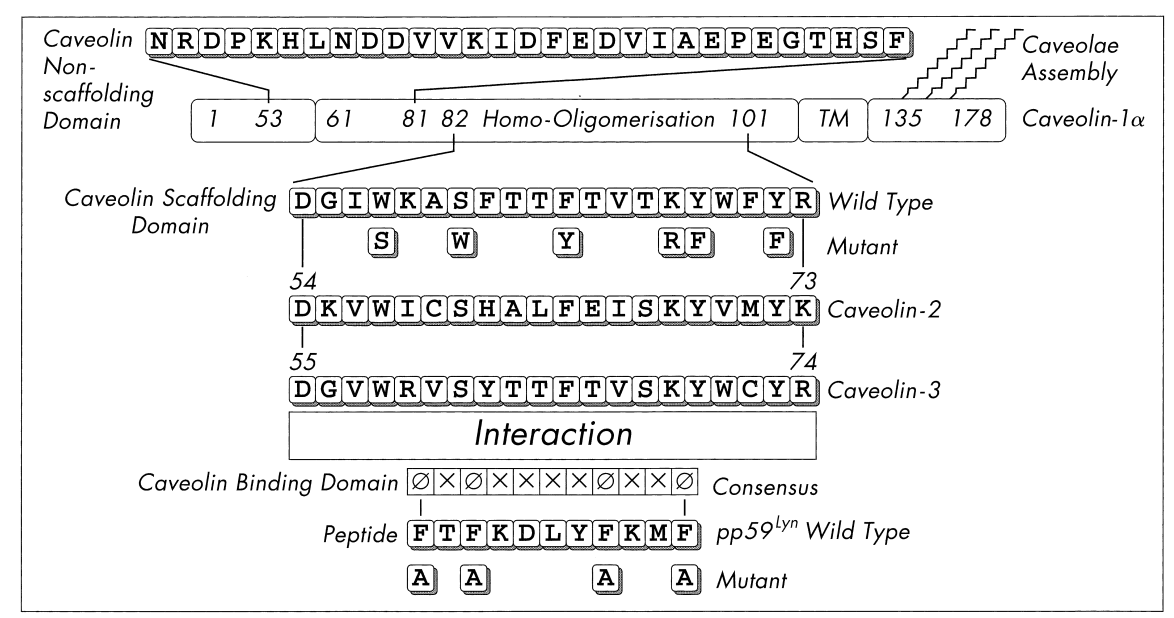

Fig. 8. Domain organization of caveolin. Structures of the (wild type and mutant) caveolinscaffolding domains of caveolin isoforms 1-3 and (wild type and mutant) caveolin binding domains of pp5 $9^{\mathrm{Ly} n}$, and the consensus sequence derived for the caveolin binding domain of signaling proteins

metabolic labeling of the photocrosslinked lipids with both $\left[{ }^{14} \mathrm{C}\right]$ inositol and $\left[{ }^{14} \mathrm{C}\right]$ glucosamine compatible with the structure of GPI lipids/anchors. The binding of Amaryl to DIGs was time-dependent. The efficiency of the photolabeling of the two GPI lipid species strongly increased with the incubation time of the adipocytes prior to the irradiation, with steady state reached after 4 to $8 \mathrm{hr}$. Binding was also non-saturable. The efficiency of the photolabeling increased in a linear fashion over a wide concentration range of $\left[{ }^{3} \mathrm{H}\right]$ Amaryl present during the incubation and could not be competed for by excess of unlabeled drug (40). Thus, Amaryl seems to intercalate with slow kinetics directly into DIGs of the adipocyte plasma membrane in close vicinity to GPI lipids/anchors, rather than bind to distinct high-affinity (proteinaceous) receptor sites.

As already mentioned, evidence is accumulating that DIGs/caveolae operate as compartments for the regulated assembly of the components for a number of signal transduction cascades $(87,88)$. Lisanti's group previously demonstrated that caveolin interacted via a specific region, the so-called caveolinscaffolding domain, with a number of signaling proteins, such as the dual-acylated nonreceptor tyrosine kinase pp59 $9^{\mathrm{Lyn}}$. These signaling proteins were associated with DIGs/caveolae by means of their lipid modification (Fig. 8) (89-91). In fact, it is this interaction between are presented (see text for details). The fatty acyl side chains of the carboxy-terminal cytosolic domain of caveolin, which presumably is anchored at the caveolar plasma membrane, are indicated. TM, membrane-interacting region of caveolin.

the caveolin-scaffolding domain and the corresponding caveolin-binding domain of the signaling proteins that keeps them in a basal inactive state, however competent for future activation/signaling $(87,88)$.

\section{Interference of Amaryl with Caveolin Function}

We recently showed that introduction of an excess of synthetic caveolin-binding domain peptide into isolated rat adipocytes by electroporation caused dissociation of $\mathrm{pp} 59^{\mathrm{Lyn}}$ from caveolin (G. Müller, S. Welte, S. Wied, W. Frick, manuscript submitted). The apparent interference with the interaction between the caveolin-scaffolding domain of caveolin and the caveolin-binding domain of $\mathrm{pp} 59^{\mathrm{Lyn}}$ (see Fig. 8) correlated well with the concentrationdependent induction of tyrosine phosphorylation of IRS-1. Data from our laboratory now provide strong evidence that sulfonylureas (SU) also can induce dissociation of pp59 $9^{\mathrm{Lyn}}$ and additional caveolar components from caveolin in isolated rat adipocytes (Fig. 9). At concentrations effective for stimulating glucose transport and tyrosine phosphorylation of caveolin, Amaryl, and to a lower degree, glibenclamide, but not tolbutamide, reduced in a concentration-dependent manner the amount of (immunoblotted, IB) pp5 $9^{\mathrm{Ly}}$ and of the (photoaffinity-labeled) GPI protein, Gcel, 


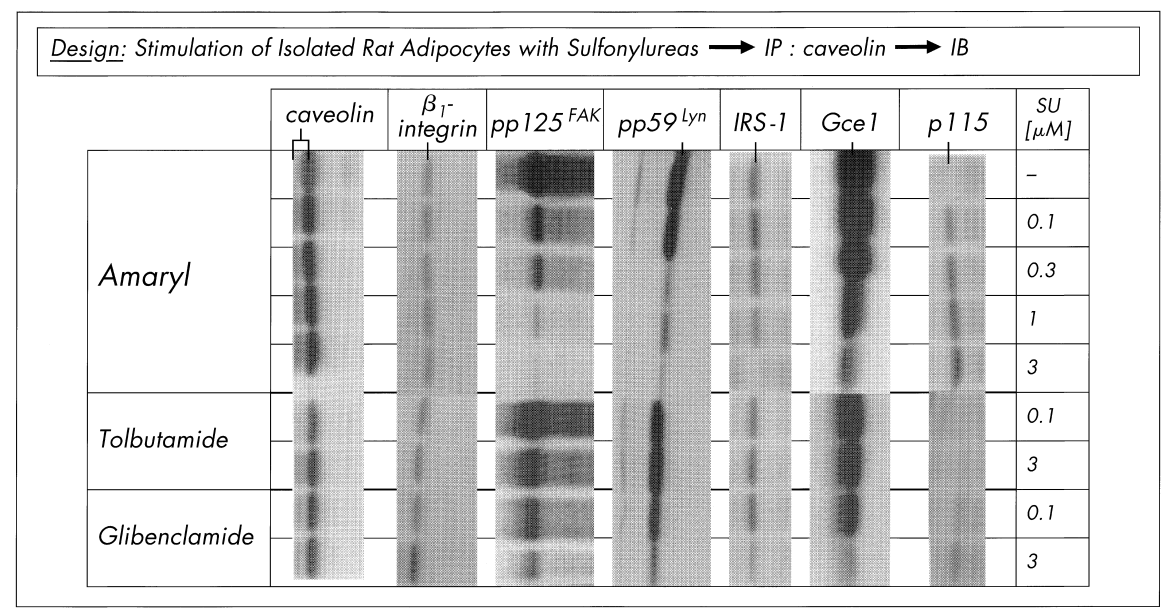

Fig. 9. Effect of sulfonylureas on complex formation between caveolin, pp59 $9^{\mathrm{Ly} n}$, and cAMPbinding ectoprotein, Gcel. (140; G. Müller, S. Welte, S. Wied, W. Frick, manuscript submitted). Isolated rat adipocytes were stimulated with increasing concentrations of different sulfonylureas for $30 \mathrm{~min}$ at $30^{\circ} \mathrm{C}$. Total plasma membranes were prepared by differential centrifugation, solubilized and subjected to immunoprecipitation (IP) with anti-caveolin antibodies. The anti-caveolin

which were co-immunoprecipitated (IP) with caveolin from sulfonylurea-treated adipocytes.

In agreement with a direct effect of Amaryl on the structural and functional organization of caveolae/DIGs, we found that sulfonylureas triggered the redistribution of specific caveolar/DIG components (Fig. 10). To demonstrate this, plasma membranes from isolated rat adipocytes stimulated with different sulfonylureas were fractionated into DIG and non-DIG structures. After purification of the DIGs by sucrose density gradient centrifugation, both fractions were assayed by immunoblotting (IB) or photoaffinity labeling for the presence of a number of caveolar and non-caveolar components. Treatment with each sulfonylurea led to a considerable decrease in the amount of the GPI protein, Gcel, and of pp5 $59^{\mathrm{Lyn}}$ in DIGs, and to a corresponding increase in non-DIG areas of the plasma membrane in a concentrationdependent fashion, with Amaryl being most potent, followed by glibenclamide, gliclazide, and lastly tolbutamide. The amount of caveolin and GLUT4 recovered with DIGs was not affected by sulfonylurea treatment, arguing for the specificity of the redistribution process (Fig. 10). The effect of a long-term treatment with sulfonylureas on the structural organization of caveolae in isolated rat adipocytes was also studied (Fig. 11). $4 \mathrm{hr}$ incubation with immunoprecipitates were immunoblotted (IB; chemiluminescence detection) with specific antibodies for the presence of $\mathrm{pp} 59^{\mathrm{Lyn}}$ and caveolin or photoaffinity-labeled with $\left.\mathrm{N}_{3}-{ }^{32} \mathrm{P}\right] \mathrm{cAMP}$ for detection of Gcel. Phosphorimages and chemiluminescence images of a typical experiment (repeated three times with similar results) are shown. The homologous immunoblotting with caveolin demonstrated comparable efficiencies of the anti-caveolin immunoprecipitations under the various conditions.

Amaryl and, to a lower degree, with glibenclamide, caused a considerable and concentrationdependent reduction of the amount of pp59 $59^{\mathrm{Lyn}}$ and Gcel. In contrast, the levels of the cytoskeletal proteins, $\operatorname{pp} 125^{\mathrm{FAK}}$ and $\beta_{1}$-integrin, as well as of caveolin in DIGs prepared from the drug-treated adipocytes, were not altered. This was demonstrated by immunoblotting of total DIG proteins with appropriate antibodies. Tolbutamide had no significant effect on the composition of DIGs (Fig. 11).

\section{Differential Involvement of SUR1/2A in Glibenclamide and Amaryl Action in Adipose, Muscle, and Neuronal Cells}

Direct insulin-mimetic and insulin-sensitizing effects of first-and second-generation sulfonylureas on isolated and cultured adipose, and muscle cells, have been described in numerous studies (42-50,92). However, the underlying molecular mechanisms, such as receptors and binding proteins, signal transduction cascades and components, remain ill-defined. For instance, in recent reports, glibenclamide was demonstrated to increase the activities of fatty acid synthase and glycerol-3-phosphate dehydrogenase and to inhibit isoproterenol-stimulated lipolysis 


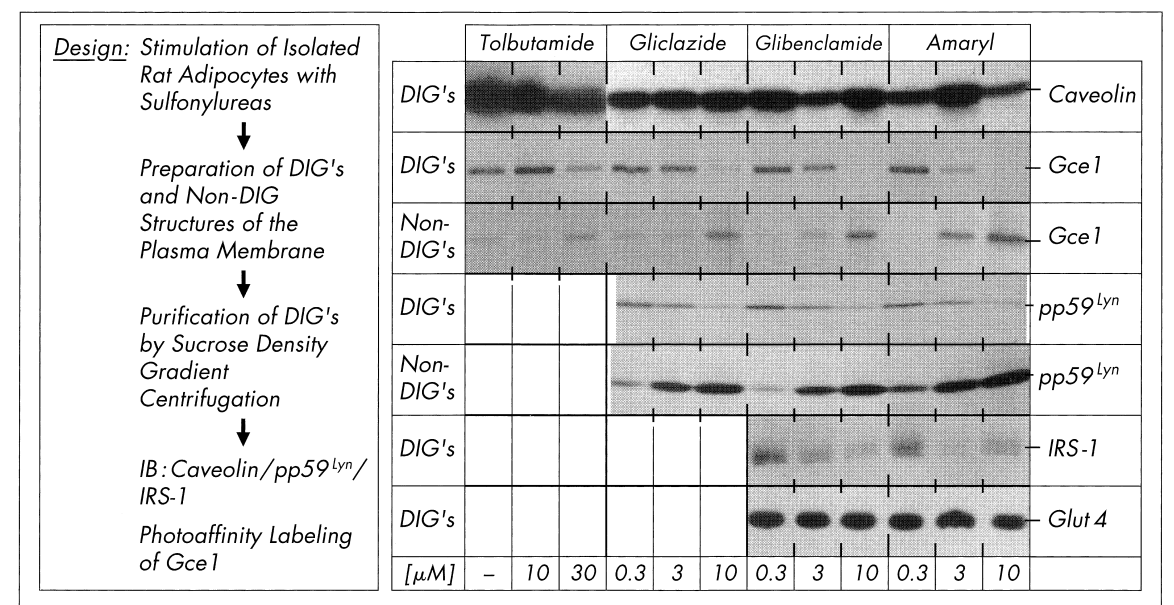

Fig. 10. Effect of sulfonylureas on the distribution of pp59 ${ }^{\mathrm{Lyn}}$ and cAMP-binding ectoprotein, Gcel, between detergent-insoluble glycolipidenriched rafts (DIGs) and non-DIG structures of the plasma membrane. (140) Isolated rat adipocytes were stimulated with increasing concentrations of different sulfonylureas for $30 \mathrm{~min}$ at $30^{\circ} \mathrm{C}$. Plasma membranes were prepared by differential centrifugation and then treated with $1 \% \mathrm{TX}-100$ for $1 \mathrm{hr}$ on ice. After centrifugation $(100,000 \mathrm{X}, 15 \mathrm{~min})$, the detergent-insoluble pellet fraction was subjected to sucrose density gradient centrifugation for purification of DIGs. They were recovered from the $8 / 20 \%$-interface of the gradient, collected by centrifugation and then solubilized in sample buffer. The detergent-soluble supernatant fraction (containing the non-DIG structures) was precipitated and then solubilized in sample buffer. Both DIGs and non-DIGs were analyzed by SDS-PAGE and immunoblotting (IB; chemiluminescence detection) for the presence of pp59 $9^{\mathrm{Lyn}}$, caveolin and glucose transporter isoforms (GLUT4) or photoaffinity labeling with $\mathrm{N}_{3}$ $\left[{ }^{32} \mathrm{P}\right]$ cAMP for the presence of Gcel. Phosphorimages and chemiluminescence images of a typical experiment (repeated twice with similar results) are shown. IRS, insulin receptor substrate.

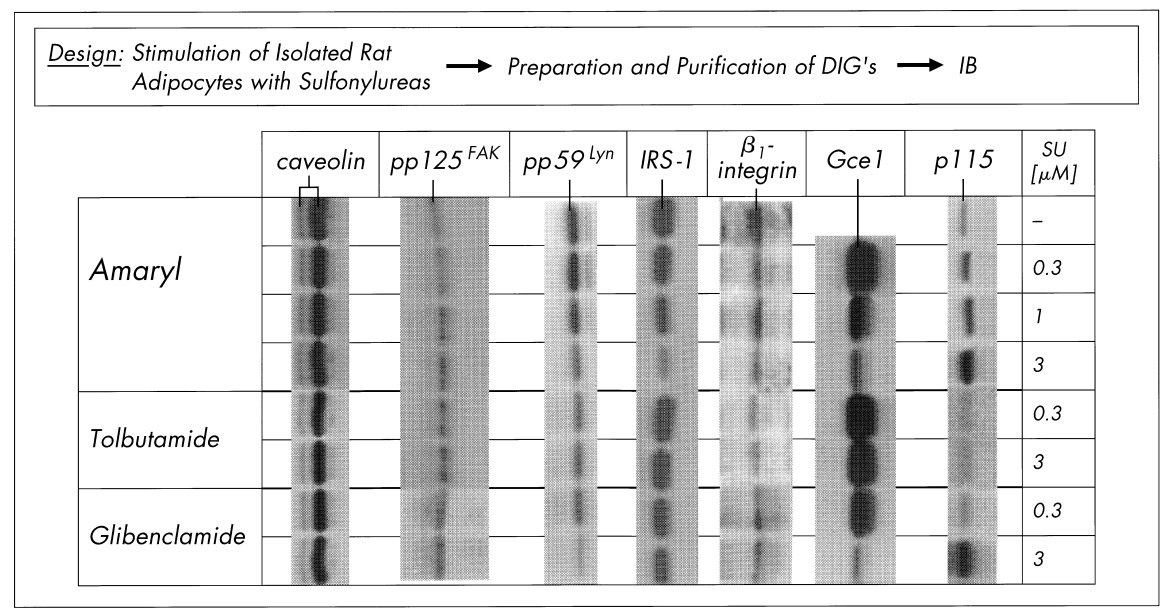

Fig. 11. Effect of sulfonylureas on the protein composition of detergent-insoluble glycolipidenriched rafts (DIGs). (140; G. Müller, S. Welte, S. Wied, W. Frick, manuscript submitted). Isolated rat adipocytes were incubated with increasing concentrations of different sulfonylureas for $4 \mathrm{hr}$ at $30^{\circ} \mathrm{C}$ and then lysed by incubation in the presence of $1 \% \mathrm{TX}-100$ for $1 \mathrm{hr}$ on ice. After centrifugation $(25,000 \mathrm{X}, 15 \mathrm{~min})$, the detergent-insoluble pellet fraction was subjected to sucrose density gradient centrifugation. DIGs were recovered from the
$8 / 20 \%$-interface of the gradient, collected by centrifugation $(100,000 \mathrm{X} g, 1 \mathrm{hr})$, solubilized in sample buffer, separated by SDS-PAGE, and analyzed for the presence of typical caveolar components by immunoblotting (IB; chemiluminescence detection) with specific antibodies. Phosphorimages and chemiluminescence images of a typical experiment (repeated three times with similar results) are shown. IRS, insulin receptor substrate; Gce, cAMP-binding ectoprotein; SU, sulfonylureas. 
(93), as well as to potentiate a multitude of typical peripheral insulin effects, such as insulinstimulated glucose transport, in isolated rat adipocytes $(46,48,49)$. Furthermore, using the isolated perfused rat hindquarter, it was shown that gliclazide alone had an immediate potent stimulatory effect on glucose uptake by skeletal muscle and, together with insulin, had an additive effect (92). These data were confirmed and extended for glibenclamide and the novel sulfonylurea, Amaryl, by our previous studies reviewed here. These results demonstrate a potent direct insulin-mimetic activity of Amaryl, in particular.

In an effort to characterize the molecular mechanism of this peripheral sulfonylurea action, Rajan et al. (94) were unable to identify high affinity sulfonylurea binding sites. Equilibrium binding or specific crosslinking of ${ }^{125} \mathrm{I}-$ labeled 5-iodo-2-hydroxyglibenclamide to the putative SUR in plasma membranes of both isolated rat adipocytes and 3T3-L1 adipocytes was performed under experimental conditions that had been successful in the identification of SUR 1 of the pancreatic $\beta$ cell. Moreover, they were unable to inhibit ${ }^{86} \mathrm{Rb}^{+}$efflux (a surrogate parameter for $\mathrm{K}_{\mathrm{ATP}}$ activity) or to increase cytosolic $\mathrm{Ca}^{2+}$ levels with glibenclamide under experimental conditions that were compatible with the demonstration of biological effects of glibenclamide in an insulin-secreting tumor cell line (94). These findings are in agreement with our data of a time-dependent and nonsaturable spontaneous insertion of Amaryl molecules directly into caveolae/DIGs of the target cell plasma membrane in close vicinity to GPI lipids, thereby, bypassing the need for a typical high affinity proteinaceous receptor-ligand interaction. This insertion mode of Amaryl action also would explain the apparent discrepancy between the free (not protein-bound) serum drug levels achieved during therapy of NIDDM patients (in the low nM-range) and the free drug concentrations required for induction of significant insulin-mimetic/sensitizing effects in vitro (in the 20- to 300-nM range). This suggests a medium to low affinity interaction of Amaryl with certain target cell structures (see below).

In contrast, several investigators have described specific binding of sulfonylureas in rodent adipocytes and skeletal muscle. For instance, rat adipocyte membranes exhibited specific, saturable glibenclamidebinding $\left(\mathrm{K}_{\mathrm{d}} \sim 1-3 \mu \mathrm{M}\right)$, which was displaced by other sulfonylureas (49). This apparent glibenclamide-binding and the functional response to glibenclamide were attributed to the presence of SUR1 in adipose and muscle cells, based on the following experimental evidence: (I) Draznin et al. $(95,96)$ reported that glibenclamide increased cytosolic $\mathrm{Ca}^{2+}$-levels in isolated rat adipocytes in a concentration-dependent manner by promoting $\mathrm{Ca}^{2+}$ influx through voltage-dependent $\mathrm{Ca}^{2+}$ channels. This effect was blocked by nitrendipine, an L-type $\mathrm{Ca}^{2+}$ channel antagonist. (II) Kim, Zemel and coworkers $(97,98)$ demonstrated that cytosolic $\mathrm{Ca}^{2+}$ can modulate de novo lipogenesis and lipolysis in a coordiated fashion in both rodent and human adipocytes. (III) In addition, they measured sustained increases in cytosolic $\mathrm{Ca}^{2+}$ levels upon glibenclamide challenge (10-20 $\mu \mathrm{M})$ in human adipocytes, but not in human preadipocytes (93). (IV) The elevation in cytosolic $\mathrm{Ca}^{2+}$ correlated nicely with the activation of fatty acid synthase and glycerol-3-phosphate dehydrogenase as well as the inhibition of lipolysis in human adipocytes, with the glibenclamide responses in all these cases completely counteracted by the KCO, diazoxide (93). (V) In extending these findings to the muscle, Pulido and coworkers (92) observed complete reversal of the stimulatory effect of gliclazide on glucose uptake in the perfused rat hindquarter in the presence of diazoxide. (VI) Most strikingly and unexpectedly, Shi and coworkers (93) found apparent expression of SURI in human adipocytes, according to both polymerase chain reaction and Northern blots analysis; whereas, human preadipocytes failed to do so. These data combined may be taken as evidence for a role of SUR 1 and cytosolic $\mathrm{Ca}^{2+}$ in partly mediating or supporting the insulin-mimetic/ sensitizing effects of glibenclamide in adipose and muscle cells. However, unfortunately, demonstration of SURI expression at the protein level in adipocytes by photoaffinity labeling with glibenclamide or immunoblotting with antibodies against $\beta$-cell SUR I is still lacking. Furthermore, the described $\mathrm{K}_{\mathrm{d}^{-}}$and $\mathrm{EC}_{50^{-}}$-values for glibenclamide (in the $\mu \mathrm{M}$-range) are not compatible with mediation of glibenclamide-binding and effects in adipocytes by high affinity SUR1.

Whatever molecular mechanism peripheral glibenclamide action relies upon, operation of SUR 1 and cytosolic $\mathrm{Ca}^{2+}$ during Amaryl signaling and action in adipocytes seems unlikely for several reasons. (I) Stimulation of lipogenesis, glycogenesis, glucose transport, GS dephosphorylation, IRS-1 tyrosine phosphorylation, 
and $\mathrm{pp} 59^{\mathrm{Lyn}}$ kinase activity in isolated rat adipocytes in response to glibenclamide are reduced by diazoxide to $43-73 \%$ and by nitrendipine to $31-45 \%$, confirming the involvement of SUR 1/cytosolic $\mathrm{Ca}^{2+}$ in glibenclamide action in peripheral cells (Table 1). In contrast, the Amaryl effects are only marginally downregulated by $8-24 \%$ (diazoxide) and $4-16 \%$ (nitrendipine). (II) In the presence of diazoxide, both the glibenclamide- and Amarylinduced elevations of cytosolic $\mathrm{Ca}^{2+}$ are reduced dramatically to a similar degree (Table 1). Since the stimulatory effects of glibenclamide and Amaryl on glucose utilization and its regulatory mechanisms are suppressed only partially or not at all, respectively, under conditions that almost completely blocked $\mathrm{Ca}^{2+}$ influx and, thereby, SUR 1 action, $\mathrm{Ca}^{2+}$ independent signaling processes are triggered by glibenclamide and, in particular, Amaryl. (III) Photoaffinity labeling studies with authentic $\left[{ }^{3} \mathrm{H}\right]$ Amaryl and isolated rat adipocytes do not result in specific radiolabeling of a 140to $150-\mathrm{kDa}$ polypeptide corresponding to the size of $\beta$-cell SUR 1 under experimental conditions, which leads to covalent crosslinking of Amaryl to GPI lipids of adipocyte plasma membrane DIGs (see above). (IV) The $\beta$-cell activity, as reflected in binding affinity and depolarization potency of Amaryl, is significantly lower, compared with glibenclamide and most likely based predominantly on SURX, rather than SUR 1 (see above). As a consequence, one would expect lower insulinmimetic/sensitizing signaling by Amaryl vs. glibenclamide, provided the molecular basis for peripheral Amaryl action relies on the same SUR as the Amaryl-induced insulin release from $\beta$ cells. As already outlined in detail, the opposite is the case, with Amaryl exhibiting a significantly higher capability for insulinmimetic signaling, direct stimulation of glucose utilization, and insulin-independent blood glucose decrease than glibenclamide.

Table 1. Effect of diazoxide and nitrendipine on the modulation of cytosolic $\mathrm{Ca}^{2+}$ levels, glucose metabolism, and signaling by glibenclamide and Amaryl

$\%$ Sulfonylurea-induced effect left in the presence of diazoxide/nitrendipine

\begin{tabular}{lcccc}
\hline Effect & $\begin{array}{c}\text { Glibenclamide } \\
\text { Diazoxide }\end{array}$ & $\begin{array}{c}\text { Glibenclamide } \\
\text { Nitrendipine }\end{array}$ & $\begin{array}{c}\text { Amaryl } \\
\text { Diazoxide }\end{array}$ & $\begin{array}{c}\text { Amaryl } \\
\text { Nitrendipine }\end{array}$ \\
\hline Lipogenesis & $27 \pm 8$ & $61 \pm 11$ & $80 \pm 6$ & $95 \pm 6$ \\
Glycogenesis & $38 \pm 11$ & $58 \pm 7$ & $79 \pm 8$ & $90 \pm 6$ \\
Glucose Transport & $52 \pm 14$ & $65 \pm 10$ & $89 \pm 8$ & $98 \pm 8$ \\
GS Dephosphorylation & $44 \pm 9$ & $68 \pm 9$ & $81 \pm 5$ & $94 \pm 7$ \\
IRS-1 Phosphorylation & $57 \pm 10$ & $69 \pm 10$ & $85 \pm 7$ & $92 \pm 10$ \\
Caveolin Phosphorylation & $35 \pm 6$ & $56 \pm 9$ & $92 \pm 8$ & $96 \pm 8$ \\
pp59 & $42 \pm 7$ & $55 \pm 6$ & $89 \pm 6$ & $90 \pm 5$ \\
Cytosolic Ca $^{2+}$ & $6 \pm 1$ & $47 \pm 7$ & $10 \pm 2$ & $41 \pm 7$ \\
& & & & \\
\hline
\end{tabular}

Isolated rat adipocytes prepared as described previously (51) were treated with $10 \mu \mathrm{M}$ Amaryl or glibenclamide alone or in combination with $10 \mu \mathrm{M}$ diazoxide or $30 \mu \mathrm{M}$ nitrendipine for $30 \mathrm{~min}$ at $30^{\circ} \mathrm{C}$ prior to assaying lipogenesis for $90 \mathrm{~min}$ (136), glycogenesis for $60 \mathrm{~min}$ (42), 2-deoxyglucose transport for $20 \mathrm{~min}$ (51), GS dephosphorylation for $15 \mathrm{~min}$ (125), IRS-1 and caveolin tyrosine phosphorylation for $10 \mathrm{~min}(40,137)$, and cytosolic $\mathrm{Ca}^{2+}$ levels for 5 min. Prior to fluorometric $\mathrm{Ca}^{2+} \mathrm{mea}^{-}$ surement, the adipocytes were washed three times (by flotation) with Hepes-based salt solution (HBSS); $140 \mathrm{mM} \mathrm{NaCl}$, $0.8 \mathrm{mM} \mathrm{MgSO}_{4}, 1.8 \mathrm{mM} \mathrm{CaCl}_{2}, 0.9 \mathrm{mM} \mathrm{NaH}_{2} \mathrm{PO}_{4}, 4 \mathrm{mM} \mathrm{NaHCO}_{3}, 5 \mathrm{mM}$ glucose, $2 \mathrm{mM}$ sodium pyruvate, $2 \mathrm{mM}$ glutamine, $20 \mathrm{mM} \mathrm{N}$-2-hydroxyethylpiperazine-N-2-ethanesulfonic acid (HEPES), 1\% bovine serum albumin]. The cells were then loaded with Fura-2-acetoxymethyl ester $(10 \mu \mathrm{M})$ in the same buffer for $45 \mathrm{~min}$ at $37^{\circ} \mathrm{C}$ in the dark with continuous shaking. For removal of extracellular dye, the cells were washed three times with HBSS and resuspended in HBSS at $3.5 \times 10^{5}$ cells/ $\mathrm{ml}$. Cytosolic $\mathrm{Ca}^{2+}$ was determined using dual excitation $(340$ and $380 \mathrm{~nm})$ and single emission $(510 \mathrm{~nm})$ fluorometry. After the establishment of stable baseline, the response to Amaryl and glibenclamide was determined. Digitonin $(25 \mu \mathrm{M})$ and Tris/ethylene glycoe tetraammonium acetate (EGTA) $(100 \mathrm{mM})$ were used to measure maximal and minimal fluorescence to calibrate the signals. Cytosolic $\mathrm{Ca}^{2+}$ was calculated by the equation of Grynkiewicz et al. (138). The sulfonylurea-induced effect (difference of presence and absence of drug) in the absence of diazoxide and nitrendipine was set at $100 \%$ for each parameter for each sulfonylurea. The values represent means \pm standard deviation (SD) from (at least) three different adipocyte preparations, each, with determinations in quadruplicate. GS, glycogen synthase; IRS-1, insulin receptor substrate - 1. 
The differential effects of diazoxide on the insulin-mimetic activity of glibenclamide and Amaryl, as well as the lack of pronounced insulin-mimetic activity of tolbutamide in fat and muscle cells, is most easily explained by two assumptions. (I) SUR2A, but not SUR1, is involved in the extrapancreatic activity of glibenclamide, based on the high level of expression in fat and adipose tissue, as well as high sensitivity toward KCOs of SUR2A in comparison with SURl. SUR l harbors high-affinity binding sites for both sulfonylurea and benzamido moieties (see above); whereas, SUR2A exhibits the benzamido-binding site, only $(33,99)$. Since glibenclamide possesses both sulfonylurea and benzamido moieties, it interacts with SUR 1 at two sites (accounting for irreversible inhibition of KIR6.2/SUR l currents due to rare simultaneous unbinding from both the sulfonylurea- and benzamido-binding sites). However, glibenclamide interacts only with a single site on SUR2A (accounting for rapid unbinding due to dissociation from a single site, only), which may be required and sufficient for initiation of insulin-mimetic effects. The interaction of tolbutamide with SURI via its sulfonylurea moiety (accounting for its rapid reversibility on $\beta$-cell $\mathrm{K}_{\mathrm{ATP}}$ currents), but not with SUR2A (due to the missing benzamido moiety), is compatible with the observed neglegible insulin-mimetic activity of tolbutamide in peripheral cells. Thus, any (hypothetical) binding of glibenclamide (or Amaryl) to SUR 1 in fat and muscle cells would not induce insulin-mimetic signaling. (II) Amaryl binds to SUR2A with lower efficiency, compared with SURl, due to lack of a typical benzamido moiety limiting its efficiacy of insulin-mimetic signaling in peripheral cells via $\mathrm{K}_{\mathrm{ATP}}$ and $\mathrm{Ca}^{2+}$.

The latter assumption is supported indirectly by the $\beta$-cell activity and chemical structure of Amaryl. Amaryl is characterized by a significantly lower binding affinity to and depolarization potency of $\beta$-cell membranes than glibenclamide (see above). This is determined by a concerted action between the benzamidoand sulfonylurea-binding sites of SURl. The benzamido- (meglitinide-), but not the sulfonylurea- (tolbutamide-), moieties differ significantly between Amaryl and glibenclamide (see Fig. 1). Thus, the benzamido moiety of Amaryl seems to contribute less to the overall interaction than that of glibenclamide. Since binding of sulfonylureas to SUR2A is assumed to be mediated by the benzamido moiety exclusively, one might expect lower affinity of Amaryl for binding to SUR2A, compared with SUR1, as well as compared with glibenclamide.

The experimental findings and considerations mentioned above suggest that if there is some interaction of Amaryl with SUR proteins in cells of extrapancreatic tissues, SUR I may be preferred relative to SUR2A. A key question in this regard is whether binding of sulfonylureas to $K_{\text {ATP }}$ in peripheral tissues has any adverse effects $(100,101)$ and whether a sulfonylurea drug with greater $\beta$-cell (i.e. SUR I vs. SUR2A) specificity (such as possibly Amaryl) would be preferable or would lead to less impairment of ischemic preconditioning, and less predisposition to larger infarctions and dangerous arrythmias. The largest and most recent study, the UK prospective diabetes study (102), examined whether the incidence of microvascular and macrovascular complications in NIDDM patients subjected to intensive blood glucose control was influenced by the type of therapy. Interestingly, it found no difference in the mortality or diabetic end points of patients treated with insulin, glibenclamide or chlorpropamide. Since glibenclamide binds SUR2A with high affinity; whereas, chlorpropamide (structurally related to tolbutamide) is likely to exhibit greater $\beta$-cell specificity, this result suggests that interaction of sulfonylureas with SUR2A does not necessarily influence mortality rates for reasons that remain a matter of speculation (33). In any case, the proposed higher selectivity of Amaryl for SURl vs. SUR2A has to be demonstrated by direct means. This has been hampered by the fact that, even for sulfonylureas with a typical benzamido moiety (such as glibenclamide), highaffinity binding to SUR2A has not been possible to show $(13,103,104)$. This may be due to reversible binding of the drug and rapid dissociation from SUR2A when membranes containing the cloned receptors are washed during the binding protocol.

The demonstration of pronounced expression of SUR1 in neuronal cells of the brain, which explains high-affinity binding of glibenclamide to crude cortical membrane preparations (105), raises the possibility of central effects of sulfonylureas. The function of SUR 1 and its putative association with $\mathrm{K}_{\text {ATP }}$ in neurons remains unclear. However, it is known that glucose influences the membrane potential of a subset of glucose-responsive neurons in 
the hypothalamus indirectly through its oxidation to generate ATP, which in turn controls the activity of $\mathrm{K}_{\mathrm{ATP}}$ in the plasma membrane. Closure of $\mathrm{K}_{\text {ATP }}$ in response to increasing intracellular concentrations of ATP raises the cytosolic level of potassium ions, which depolarizes the neuron and increases its firing rate (106). Interestingly, the glucose-responsive neurons become hyperpolarized and, therefore, decrease their firing rate within minutes after application of leptin $(107,108)$. Leptin is a key hormone for the control of energy homeostasis, which is released by fat cells in direct proportion to cell size (i.e. degree of adiposity) and induces reduction of food intake and increase of energy expenditure (109). The inhibitory effect of leptin on the neuronal firing rate is based in part on its ability to keep the $\mathrm{K}_{\mathrm{ATP}}$ in the open configuration, thereby, lowering the membrane potential. This can be detected even in isolated patches of plasma membranes excluding a mechanism involving the transcriptional activity of leptin. Although regulation of hypothalamic neuropeptide gene expression by leptin is well described, the leptin signaling of satiety may not rely solely on the Janus kimase-signal transducers and activators of transcription (JAK-STAT) transcriptional pathway (110), but may include also the $\mathrm{K}_{\mathrm{ATP}}$ nutrition sensing system. According to this possibility, inhibition of $\mathrm{K}_{\mathrm{ATP}}$ in hypothalamic neurons should interfere with (some aspects of) leptin regulation of energy homeostasis (111).

The well-documented moderate, but continuous, weight gain of NIDDM patients during long-term treatment with conventional sulfonylureas may be based on (partial) antagonism of leptin action at the level of the hypothalamic $\mathrm{K}_{\mathrm{ATP}}$, in addition to stimulation of lipogenesis in course of increased pancreatic insulin secretion. Both events may rely on sulfonylurea-binding to SUR I in hypothalamic neurons and $\beta$ cells, respectively. Interestingly, smaller increases in body weight of NIDDM patients treated with Amaryl, compared with glibenclamide, have been revealed by preliminary clinical studies (E. Draeger, personal communication). This may be explained by a combination of diminished leptin antagonism and insulin release in response to the lower SUR 1binding and $\mathrm{K}_{\mathrm{ATP}}$ depolarization activities of Amaryl vs. glibenclamide (see above), provided that SUR1 and KIR6.2/6.1 behave similar in pancreatic $\beta$ cells and hypothalamic neurons. Interestingly, opening of the $\mathrm{K}_{\mathrm{ATP}}$ in response to leptin also has been demonstrated for cultured $\beta$ cells. Thereby, leptin antagonizes sulfonylurea-induced insulin release in vitro and may interfere with glucose-triggered insulin release in vivo. This raises the possibility that hyperleptinemia (commonly found in obesity) and, as a consequence, inhibition of $\beta$ cell depolarization is the major mechanism whereby obesity causes NIDDM, at least with regard to $\beta$ cell failure as the initial causative trigger. The relationships between leptin signaling through $\mathrm{K}_{\mathrm{ATP}}$ of both hypothalamic neurons and $\beta$ cells in vivo; its effects on neuronal firing rate, pancreatic insulin release, satiety, and weight control; and the hypothetical interference of sulfonylureas with leptin action at both hypothalamic neurons and $\beta$ cells, including the molecular mechanism(s) involved [leptin inhibition of $\mathrm{K}_{\mathrm{ATP}}$ by direct binding to SUR I (112) or, more likely, by indirect means $(113,114)]$ are important areas for future research.

\section{Molecular Model of Amaryl Action in Peripheral Cells Involving Caveolae/DIGs}

According to the experimental data just summarized, Amaryl and glibenclamide support direct glucose utilization by different mechanisms, such as interaction with caveolae/DIGs and SUR2A, respectively. From a structural point of view, this conclusion reinforces the sometimes neglected or even seemingly contradictory possibility that the sulfonylurea moiety, which is shared by both drugs, can adopt considerably different biophysical and biochemical features, depending on the residual portions (i.e. benzamido moiety) of the complete molecule. It will be a challenge to elucidate the structure-activity relationship and to develop a pharmacophore model that covers the distinct modes of interaction of Amaryl and glibenclamide with peripheral cells.

Considering the biochemical studies with isolated and cultured adipose and muscle cells, we propose the following working model for direct insulin-mimetic signaling and metabolic action by Amaryl (Fig. 12). Amaryl partitions directly into caveolae/DIG areas of adipocyte/ myocyte plasma membranes in a nonsaturable and time-dependent fashion, thereby, causing redistribution of specific DIG/caveolar components. This may be accomplished by a direct 
physical interference of Amaryl with the structure/organisation of DIGs and/or lipolytic release of GPI lipids/proteins from DIGs via Amaryl-induced activation of the GPI-PLC. As a consequence, an acylated nonreceptor tyrosine kinase (non RTK), such as pp59 ${ }^{\mathrm{Ly}}$, dissociates from caveolin and migrates into nonDIG areas of the plasma membrane, thereby, being relieved from inhibition. These events are accompanied/supported by tyrosine phosphorylation of caveolin (40), which may further destabilize the interaction or inhibit the reassociation

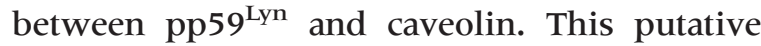
positive feedback loop between caveolin and pp $59^{\mathrm{Lyn}}$ for keeping pp $59^{\mathrm{Lyn}}$ in the active state is compatible with recent findings that, in 3T3-L1 adipocytes, the homolog of pp5 $59^{\mathrm{LYn}}, \mathrm{pp} 60^{\mathrm{Fyn}}$, is a candidate kinase for the insulin-induced tyrosine phosphorylation of caveolin (115). The activated non RTK phosphorylates IRS proteins at specific tyrosine residues and, thereby, initiates metabolic insulin-mimetic signaling to the lipid and glycogen synthesis pathways and the GLUT4 translocation apparatus along the insulin signaling cascade downstream of IRS via the PI-3K pathway (Fig. 12) (57).

Interestingly, a number of extracellular stimuli have been demonstrated to cross-talk to the insulin signal transduction chain via insulin receptor-independent tyrosine phosphorylation of IRS-1 or 2 (116-119). In contrast, mitogenic insulin-mimetic signaling to DNA synthesis, transcription, and translation via the Ras/mitogen-activated protein kinase (MAPK) pathway presumably involves tyrosine phosphorylation of the Src homology collagen (SHC) proteins; followed by docking of growth factor receptor-bound protein 2 (Grb2); and activation of nucleotide exchange factor son-ofsevenless (SOS), the small G protein, ras, and the kinases, raf, MEK kinase (MEKK), MAPK and extracellular signal related kinase kinase (MEK) and MAPK (see Fig. 12). SHC has been demonstrated to act as substrate for the insulin receptor kinase (57), but may not be accepted by pp59 ${ }^{\mathrm{Lyn}}$. The caveolae-dependent mode of insulin-mimetic metabolic signaling critically depends on the presence of a high number of DIGs/caveolae in the target cell, which is certainly true for fully differentiated cells, such as adipocytes and myocytes (78). Other dividing cell types use distinct caveolin-independent mechanisms for regulation of (i.e. keeping silent) non RTKs, thereby, guaranteeing the required degree of specificity.

Strikingly, insulin-mimetic signaling by synthetic phosphoinositolglycans (PIG), which are structurally related to the polar core glycan head groups of GPI lipids [generated by GPI-PLC cleavage; (120-123)], in isolated rat adipocytes has been demonstrated recently to involve tyrosine phosphorylation of IRS-1 by activated pp59 $9^{\text {Lyn }}$ (124-127). PIG favour the metabolic vs. the mitogenic branch of insulin ac-

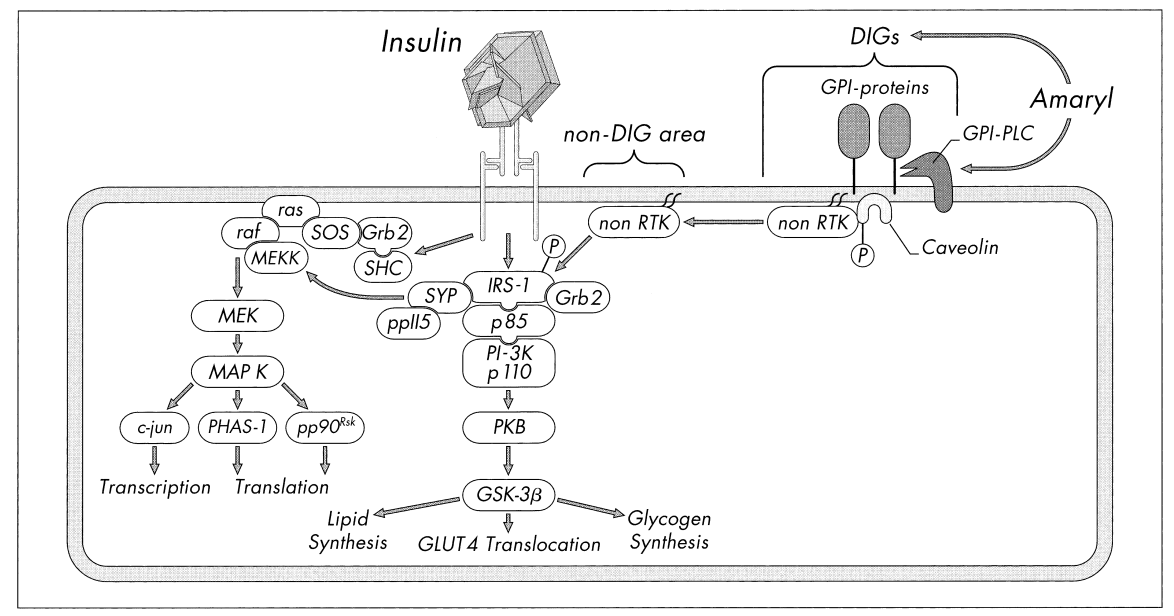

Fig. 12. Hypothetical model for insulinmimetic metabolic signaling by Amaryl via caveolae/DIGs. (See text for details). DIG, detergent-insoluble glycolipid-enriched rafts; non RTK, dual acylated non-receptor tyrosine kinase; GPIPLC, glycosyl-phosphatidylinositol-phospholipase C; IRS, insulin receptor substrate; son-of- sevenless (SOS), MAPK and extracellular signal related kinase kinase (MEK), MAPK, mitogenactivated protein kinase; Grb 2, growth factor receptor-bound protein 2 ; GSK-3 $\beta$, glycogen synthase kinase $3 \beta$ GLUT, 4 glucose transporter isoforms; 4 SHC. 
tion, as deduced from PIG stimulation of the IRS-1/PI-3K pathway, to almost the full insulin response and of the MAPK pathway to only about $40 \%$ of the maximal insulin response (125). Thus, it is tempting to speculate that pp5 $9^{\mathrm{Lyn}}$ and homologous non RTKs are the common key players for the positive cross-talk of various signaling pathways to insulin signaling via tyrosine phosphorylation of IRS-1 and 2, which predominantly leads to metabolic insulin action. The signaling cascades and components responsible for appropriate redistribution/activation of non RTKs, such as pp59 $9^{\mathrm{Lyn}}$, in response to the various signals may be shared in part or differ completely, as is apparently the case for Amaryl and PIG. We recently identified a 115$\mathrm{kDa}$ polypeptide of the adipocyte plasma membrane that was required for insulin-mimetic metabolic signaling by PIG $(88,126)$, but apparently did not interact with Amaryl (see above). The molecular elucidation of the signaling pathways for Amaryl and PIG upstream of pp59 $9^{\mathrm{Lyn}}$ should reveal novel targets for pharmacological cross-talk to metabolic insulin signaling.

Certainly, the proposed molecular mode of Amaryl action in peripheral cells on basis of the caveolin/pp59 $9^{\mathrm{Ly}}$ pathway does not exclude the operation of other additional mechanisms. The demonstrated Amaryl-induced increase in GLUT1/4 gene/protein expression $(55,56)$ and diacylglycerol production $(70)$ in conjunction with activation of certain protein kinase $\mathrm{C}$ isoforms, which is assumed to mediate GLUT4 translocation in response to insulin at least in part (57), may contribute to and/ or enhance the direct insulin-mimetic and/or insulin-sensitizing effect of Amaryl on glucose transport. Furthermore, first- and secondgeneration sulfonylureas have been shown to affect other systems as well, including: modulating catecholamine release and metabolism; blocking $\mathrm{K}^{+}$channels other than the $\mathrm{K}_{\mathrm{ATP}}$; inhibiting transporters, such as multidrug resistance proteins and acidic dopaminic metabolite transporters; increasing cytosolic $\mathrm{Ca}^{2+}$ concentrations in $\mathrm{K}_{\mathrm{ATP}}$-independent fashion in cells other than the $\beta$ cells; and forcing development of the aorta. However, these extrapancreatic effects are observed at glibenclamide concentrations in the $\mu \mathrm{M}$ range only. In the absence of (time-dependent) accumulation of the drug at the corresponding target, as is most likely the case for Amaryl in DIGs/caveolae (see above), and taking into account the therapeutic serum concentrations of Amaryl (see below), these mechanisms defined in vitro presumably do not contribute to the in vivo hypoglycemic activity of Amaryl.

The receptor-independent and timedependent interaction of sulfonylureas with peripheral cells via insertion into DIGs/caveolae apparently is most efficient for Amaryl, compared with conventional sulfonylureas, such as glibenclamide. This may facilitate operation of this mechanism of insulin-mimetic signaling in vivo, despite the fact that the total (free and protein-bound) serum concentration of Amaryl measured after once daily oral treatment of NIDDM patients with $4 \mathrm{mg}$ for 7 days approached only about $0.7 \mu \mathrm{M}$ at $2.5 \mathrm{hr}$ after the last administration (128-130). This concentration is about one to two orders of magnitude below the total drug levels effective in vitro in the presence of $1 \%$ bovine serum albumin in the incubation medium (i.e. 10-50 $\mu \mathrm{M}$ ), assuming a similar high-protein binding of Amaryl (about $99.5 \%$ ) in vivo and in vitro. Compatible with the proposed time-dependent and functional accumulation of Amaryl molecules in DIGs of the target cell, we observed a considerable leftward shift of the concentrationresponse curves for Amaryl activation of the GPI-PLC, lipid synthesis, and anti-lipolysis in rat adipocytes upon increasing the incubation period $(40,42)$.

\section{Conclusions}

The reviewed pharmacological and biochemical findings lead to the following conclusions on the pancreatic and extrapancreatic activity of sulfonylureas. (I) The binding, depolarisation, and insulin-releasing characteristics of Amaryl and glibenclamide indicate that different sulfonylureas can interact with different SURs of a common pore-forming subunit that constitute the $K_{\text {ATP. }}$ (II) Sulfonylureas appear to decrease blood glucose by induction of insulin release and in conjunction with an insulin-independent activity, even after a single oral administration to normal animals. (III) Amaryl exhibits more pronounced insulin-independent blood glucoselowering activity, compared with conventional sulfonylureas. (IV) This insulin-independent activity can be explained by direct stimulation of glucose transport (via GLUT4 translocation) and non-oxidative glucose metabolism in fat and muscle cells. (V) At the molecular level, Amaryl seems to intercalate spontaneously into caveo- 
lae or DIGs of fat and muscle cells, thereby, (a) activating a GPI-PLC, (b) causing redistribution of caveolar components, such as GPI lipids, GPI proteins, and non RTKs, (c) triggering tyrosine phosphorylation of caveolin, and (d) inducing downstream cross-talk to the insulin signaling cascade via insulin receptorindependent tyrosine phosphorylation of IRS1/2 (see Fig. 12). (VI) The concentrations of Amaryl required for insulin-mimetic signaling events and activation of glucose transport/metabolism in isolated adipose cells are higher than the therapeutic plasma drug levels. (VII) Provided that the observed time-dependent accumulation of Amaryl in caveolae/DIGs of peripheral cells represents the initial trigger for the described cross-talk from caveolae to the insulin signaling cascade and would also occur in vivo, the insulin-independent blood glucose-lowering activity of Amaryl might become effective during therapy, even at lower drug concentrations, due to the longer exposure times compared to in vitro. (VIII) In light of the ongoing discussion of hyperinsulinism and long-lasting blockade of $\mathrm{K}_{\mathrm{ATP}}$ as a concern in the pathogenesis and therapy of NIDDM including diabetic late complications (e.g. cardiovascular side effects), one may speculate that the higher insulin-independent blood glucoselowering activity of Amaryl might be of therapeutic relevance.

In summary, our studies provide the following mechanistic explanations for the therapeutic advantages of Amaryl vs. secondgeneration sulfonylureas, such as glibenclamide. The faster and longer action (131, 132), the lower doses required (133), and the lower insulin levels generated $(34,37,38)$ seem to rely on a combination of reduced insulin secretion and increased direct, as well as insulinstimulated, glucose utilization in peripheral tissues. The lower cardiovascular risks (134, 135) and atherogenic potential (Y. Satoh and S. Shakuto, manuscript submitted) may be based on higher selectivity for the $\mathrm{K}_{\mathrm{ATP}}$ of the $\beta$ cell vs. other tissues. At the molecular level the pharmacological characteristics of Amaryl may be explained in part by its interaction with SURX in the pancreatic $\beta$ cell and DIGs/caveolae in adipose and muscle cells.

\section{Acknowledgements}

The following coworkers contributed to the biochemical and pharmacological studies with
Amaryl during the past decade: A. Crecelius, E.-A. Dearey, K. Geisen, F. Girbig, U. Gutjahr, H. Gögelein, D. Hartz, C. Jung, S. Kowalewski, A. Korndörfer, W. Kramer, K.-H. Lehr, R. Okonomopulos, J. Pünter, A. Unkelbach, E.-M. Wetekam and S. Wied, (all Aventis Pharma Germany); M. Bähr, M. v. Holtey, and J. Eckel (all Diabetes Institute Düsseldorf Germany); M. Kobayashi (University of Tokayama, Japan); Y. Satoh and S. Shakuto (Aventis Pharma Ltd. Japan)

\section{*Note added in proof}

After completion of the revision process, first results from a placebo-controlled, double-blind, cross-over clinical study on Amaryl effects on peripheral insulin sensitivity of healthy, glucose tolerant and insulin resistant offspring of patients with NIDDM were reported (Volk A, Maerker E, Rett K, Häring HU, Overkamp D (2000) Glimepiride-effects on peripheral insulin sensitivity. Diabetologia 43 (supplement 1):A39 [abstract]). Acute infusion of Amaryl during a three-step hyperinsulinemic euglycemic glucose clamp increased significantly the metabolic glucose clearance rate at low and moderate insulin levels. Since stimulation of pancreatic insulin secretion was suppressed by somatostatin, Amaryl apparently exerts insulinsensitizing/mimetic activity in peripheral tissues of relatives of NIDDM patients compatible with the animal and in vitro findings reviewed here.

\section{References}

(space limitation necessitated restriction of citations to reviews and studies directly related to Amaryl action which provide experimental details, more intense discussions of specific items and additional references)

1. Lebovitz HE. (1990) Oral hypoglycemic agents. In: Rifkin H, Porte D. (eds.) Ellenberg and Rifkin's Diabetes mellitus. Theory and Practise. Elsevier, New York, pp. 554-574.

2. Ashcroft SJH, Ashcroft FM. (1992) The sulfonylurea receptor. Biochim. Biophys. Acta 1175: 45-59.

3. Philipson LH. (1995) ATP-sensitive $\mathrm{K}^{+}$channels: paradigm lost, paradigm regained. Science 270: 1159.

4. Aguilar-Bryan L, Bryan J. (1999) Molecular biology of adenosine triphosphate-sensitive potassium channels. Endocr. Rev. 20: 101-135. 
5. Tabuchi H, Yamamoto $H$, Matsumoto $K$, et al. (2000) Regulation of insulin secretion by overexpression of $\mathrm{Ca}^{2+}$ /calmodulin-dependent protein kinase II in insulinoma MIN6 cells. Endocrinology 141: 2350-2360.

6. Easom RA. (1999) CaM kinase II: a protein kinase with extraordinary talents germane to insulin exocytosis. Diabetes 48: 675-684.

7. Popoli M. (1993) Synaptotagmin is endogenously phosphorylated by $\mathrm{Ca}^{2+} /$ calmodulin protein kinase II in synaptic vesicles. FEBS Lett. 317: 85-88.

8. Matsumoto K, Ebihara K, Yamamoto H, et al. (1999) Cloning from insulinoma cells of synapsin I associated with insulin secretory granules. J. Biol. Chem. 274: 2053-2059.

9. Mshlig M, Wolter S, Mayer P, et al. (1997) Insulinoma cells contain an isoform of $\mathrm{Ca}^{2+}$ / calmodulin-dependent protein kinase II $\delta$ associated with insulin secretion vesicles. Endocrinology 138: 2577-2584.

10. Skeer JM, Degano P, Coles B, Potier M, Ashcroft FM, Ashcroft SJH. (1994) Determination of the molecular mass of the native beta-cell sulfonylurea receptor. FEBS Lett. 338: 98-102.

11. Bryan J, Aguilar-Bryan L. (1999) Sulfonylurea receptors: ABC transporters that regulate ATPsensitive $\mathrm{K}^{+}$channels. Biochim. Biophys. Acta 1461: 285-303.

12. Clement IV JP, Kunjilwar K, Gonzalez G, et al. (1997) Association and stoichiometry of $\mathrm{K}_{\mathrm{ATP}}$ channel subunits. Neuron 18: 827-838.

13. Bryan LA, Nichols CG, Wechsler SW, et al. (1995) Cloning of the $\beta$ cell high-affinity sulfonylurea receptor: a regulator of insulin secretion. Science 268: 423-426.

14. Inagaki $\mathrm{N}$, Gonoi $\mathrm{T}$, Clement JP, et al. (1996) Reconstitution of $\mathrm{I}_{\mathrm{KATP}}$ : an inward rectifier subunit plus the sulfonylurea receptor. Science 270: 1167-1170.

15. Ueda K, Komine J, Matsuo M, Seino S, Amachi T. (1999) Cooperative binding of ATP and MgADP in the sulfonylurea receptor is modulated by glibenclamide. Proc. Natl. Acad. Sci. USA 96: 1268-1272.

16. Babenko AP, Aguilar-Bryan L, Bryan J. (1998) A view of SUR/KIR6.X, $\mathrm{K}_{\mathrm{ATP}}$ channels. Annu. Rev. Physiol. 60: 667-687.

17. Ashfield R, Gribble FM, Ashcroft SJ, Ashcroft FM. (1999) Identification of the high-affinity tolbutamide site on the SURI subunit of the K(ATP) channel. Diabetes 48: 1341-1347.

18. Babenko AP, Gonzalez G, Bryan J. (1999) The tolbutamide site of SUR 1 and a mechanism for its functional coupling to $\mathrm{K}_{\text {ATP }}$ channel closure. FEBS Lett. 459: 367-376.

19. Aguilar-Bryan L, Clement JP, Gonzalez G, Kunjilwar K, Babenko A, Bryan J. (1998) Toward understanding the assembly and structure of $\mathrm{K}_{\mathrm{ATP}}$ channels. Physiol. Rev. 78: 227-245.
20. Uhde I, Toman A, Gross I, Schwanstecher C, Schwanstecher M. (1999) Identification of the potassium channel opener site on sulfonylurea receptors. J. Biol. Chem. 274: 28079-28082.

21. Thomas PM, Cote GJ, Wohlik N, et al. (1995) Mutations in the sulfonylurea receptor gene in familial hyperinsulinemic hypoglycemia of infancy. Science 268: 426-429.

22. Thomas $P$, Ye Y, Lightner E. (1996) Mutations of the pancreatic islet inward rectifier also lead to familial persistent hyperinsulinemic hypoglycemia of infancy. Hum. Mol. Gen. 5: 18091812.

23. Kane C, Shepherd RM, Squires PE, et al. (1996) Loss of functional $\mathrm{K}_{\mathrm{ATP}}$ channels in pancreatic $\beta$ cells causes persistent hyperinsulinemic hypoglycemia of infancy. Nature Med. 2: 1344-1347.

24. Gribble FM, Tucker SJ, Ashcroft FM. (1997) The essential role of the Walker A motifs of SUR 1 in K-ATP channel activation by MgADP and diazoxide. EMBO J. 16: 1145-1152.

25. Nichols CG, Shyng S-L, Nestorowicz A. (1996) Adenosine diphosphate as an intracellular regulator of insulin secretion. Science 272: 1785-1787.

26. Shyng S-L, Ferrigni T, Sheppard JB. (1998) Functional analysis of novel mutations in the sulfonylurea receptor 1 associated with persistent hyperinsulinemic hypoglycemia of infancy. Diabetes 47: 1145-1151.

27. Müller G, Hartz D, Pünter J, Ökonomopulos R, Kramer W. (1994) Differential interaction of glimepiride and glibenclamide with the $\beta$-cell sulfonylurea receptor: I. Binding characteristics. Biochim. Biophys. Acta 1191: 267-277.

28. Kramer W, Müller G, Girbig F, et al. (1995) The molecular interaction of sulfonylureas with $\beta$ cell ATP-sensitive $\mathrm{K}^{+}$-channels. Diabetes Res. Clin. Pract. 28 (Suppl.): S67-S80.

29. Kramer W, Müller G, Girbig F, et al. (1994) Differential interaction of glimepiride and glibenclamide with the $\beta$-cell sulfonylurea receptor: II. Photoaffinity labeling of a $65-\mathrm{kDa}$ protein with $\left[{ }^{3} \mathrm{H}\right]$ glimepiride. Biochim. Biophys. Acta 1191: 278-290.

30. Kramer W, Geisen K, Müller G. (1996) Characterization of the molecular mode of action of the sulfonylurea, glimepiride, at pancreatic $\beta$ cells. Horm. Metab. Res. 28: 464-468.

31. Kramer W, Ökonomopulos R, Pünter J, Summ H-D. (1988) Direct photoaffinity labeling of the putative sulfonylurea receptor in rat $\beta$-cell tumor membranes by $\left[{ }^{3} \mathrm{H}\right]$ glibenclamide FEBS Lett. 229: 355-359.

32. Ashcroft FM. (1996) Mechanisms of the glycaemic effects of sulfonylureas. Horm. Metab. Res. 28: 456-463.

33. Ashcroft FM, Gribble FM. (1999) ATP-sensitive $\mathrm{K}^{+}$channels and insulin secretion: their role in health and disease. Diabetologia 42: 903-919. 
34. Draeger E. (1995) Clinical profile of glimepiride. Diabetes Res. Clin. Pract. 28: S139-S146.

35. Langtry HD, Balfour JA. (1998) Glimepiridea review of its pharmacological and clinical efficacy in the management of type 2 diabetes mellitus. Drugs 55: 563-584.

36. Tsumura K. (1995) Clinical evaluation of glimepiride (HOE490) in NIDDM, including a double blind comparative study versus gliclazide. Diabetes Res. Clin. Pract. 28: S147-S149.

37. Dills DG, Schneider J, Glimepiride/Glyburide Research Group. (1996) Clinical evaluation of glimepiride versus glyburide in NIDDM in a double-blind comparative study. Horm. Metab. Res. 28: 426-429.

38. Draeger KE, Wernicke-Panten K, Lomp HJ. (1996) Long-term treatment of type 2 diabetic patients with a new oral anti-diabetic agent glimepiride (Amaryl): a double-blind comparison with glibenclamide. Horm. Metab. Res. 28: 419-425.

39. Müller G, Satoh Y, Geisen K. (1995) Extrapancreatic effects of sulfonylureas - a comparison between glimepiride and conventional sulfonylureas. Diabetes Res. Clin. Pract. 28 (Suppl.): S115-S137.

40. Müller G, Geisen K. (1996) Characterization of the molecular mode of action of the sulfonylurea, glimepiride, at adipocytes. Horm. Metab. Res. 28: 469-487.

41. Geisen K. (1988) Special pharmacology of the new sulfonylurea glimepiride. Drug. Res. 38: 1120-1130.

42. Müller G, Wied S, Wetekam E-M, Crecelius A, Unkelbach A, Pünter J. (1994) Stimulation of glucose utilization in $3 \mathrm{~T} 3$ adipocytes and rat diaphragm in vitro by the sulfonylureas, glimepiride and glibenclamide, is correlated with modulations of the cAMP regulatory cascade. Biochem. Pharmacol. 48: 985-996.

43. Davidson MB, Molnar G, Furman A, Yamaguchi D. (1991) Glyburide-stimulated glucose transport in cultured muscle cells via protein kinase C-mediated pathway requiring new protein synthesis. Diabetes 40: 1531-1538.

44. Rogers BJ, Standaert ML, Pollet RJ. (1987) Direct effects of sulfonylurea agents on glucose transport $\mathrm{BC}_{3} \mathrm{H}-1$ myocyte. Diabetes 36: 1292-1296.

45. Bak JF, Schmitz O, Sorensen NS, Pedersen O. (1989) Post-receptor effects of sulfonylurea on skeletal muscle glycogen synthase activity in type II diabetic patients. Diabetes 38: 1343-1350.

46. Jacobs DB, Jung CY. (1985) Sulfonylurea potentiates insulin-induced recruitment of glucose transport carrier in rat adipocytes. J. Biol. Chem. 260: 2593-2596.

47. Altan N, ALtan VM, Mikolay L, Larner J, Schwartz CFW. (1985) Insulin-like and insulin-enhancing effects of the sulfonylurea glyburide on rat adipose glycogen synthase. $\mathrm{Di}$ abetes 34: 281-286.
48. Jacobs DB, Jung CY. (1985) Sulfonylurea potentiates insulin-induced recruitment of glucose transport carrier in rat adipocytes. J. Biol. Chem. 260: 2593-2596.

49. Martz A, Jo I, Jung CY. (1988) Sulfonylurea binding to adipocyte membrane and potentiation of insulin stimulated hexose transport. $J$. Biol. Chem. 264: 13672-13678.

50. Maloff BL, Lockwood DH. (1981) In vitro effects of a sulfonylurea on insulin action in adipocytes. J. Clin. Invest. 68: 85-90.

51. Müller G, Wied S. (1993) The sulfonylurea drug, glimepiride, stimulates glucose transport, glucose transporter translocation, and dephosphorylation in insulin-resistant rat adipocytes in vitro. Diabetes 42: 1852-1867.

52. Pessin JE, Thurmond DC, Elmendorf JS, Coker KJ, Okada S. (1999) Molecular basis of insulin-stimulated GLUT4 vesicle trafficking. J. Biol. Chem. 274: 2593-2596.

53. Holman GD, Kasuga M. (1997) From receptor to transporter: insulin signalling to glucose transport. Diabetologia 40: 991-1003.

54. Czech MP, Corvera S. (1999) Signaling mechanisms that regulate glucose transport. J. Biol. Chem. 274: 1865-1868.

55. Bähr M, v. Holtey M, Müller G, Eckel J. (1995) Direct stimulation of myocardial glucose transport and glucose transporter (Glut1) and Glut4 protein expression by the sulfonylurea glimepiride. Endocrinology 136: 2547-2553.

56. Eckel J. (1996) Direct effects of glimepiride on protein expression of cardiac glucose transporters. Horm. Metab. Res. 28: 508-511

57. Gustafson TA, Moodie SA, Lavan BE. (1999) The insulin receptor and metabolic signaling. In: Blaustein, Greger, Grunicke, et al (eds.) Reviews in Physiology, Biochemistry and Pharmacology, vol. 137. Springer, Berlin, pp. 71-192.

58. White MF. (1997) The insulin signalling system and the IRS proteins. Diabetologia 40: S2-S17.

59. White MF. (1998) The IRS-signalling system: a network of docking proteins that mediate insulin action. Mol. Cell. Biochem. 182: 3-11.

60. Coffer PJ, Jin J, Woodgett JR. (1998) Protein kinase B (c-Akt): a multifunctional mediator of phosphatidyl 3-kinase activation. Biochem. J. 335: 1-13.

61. Cohen P, Alessi DR, Cross DAE. (1997) PDK1, one of the missing links in insulin signal transduction? FEBS Lett. 410: 3-10.

62. White MF. (1998) The IRS-signalling system: a network of docking proteins that mediate insulin action. Mol. Cell. Biochem. 182: 3-11.

63. Shepherd PR, Withers DJ, Siddle K. (1998) Phosphoinositide 3-kinase: the key switch mechanism in insulin signalling. Biochem. J. 333: 471-490.

64. Nystrom FH, Quon MJ. (1999) Insulin signalling: Metabolic pathways and mechanisms for specificity. Cell. Signal. 11: 563-574. 
65. Araki E, Lipes MA, Patti ME, et al. (1994) Alternative pathway of insulin signaling in mice with targeted disruption of the IRS-1 gene. Nature 372: 186-190.

66. Tamemoto H, Kadowaki T, Tobe K, et al. (1994) Insulin resistance and growth retardation in mice lacking insulin receptor substrate-1. $\mathrm{Na}$ ture 372: 182-186.

67. Withers DJ, Gutierrez JS, Towery H, et al. (1998) Disruption of IRS-2 causes type 2 diabetes in mice. Nature 391: 900-904.

68. Lavan BE, Fantin VR, Chang ET, Lane WS, Keller SR, Lienhard GE. (1997) A novel 160$\mathrm{kDa}$ phosphotyrosine protein in insulintreated embryonic kidney cells is a new member of the insulin receptor substrate family. $J$. Biol. Chem. 272: 21403-21407.

69. Liu SCH, Wang Q, Lienhard GE, Keller SR. (1999) Insulin receptor substrate 3 is not essential for growth or glucose homeostasis. $J$. Biol. Chem. 274: 18093-18099.

70. Takada Y, Takata Y, Iwanishi M, et al. (1996) Effect of glimepiride (HOE490) on insulin receptors of skeletal muscles from genetically diabetic KK-Ay mouse. Eur. J. Pharmacol. 308: 205-2 10.

71. Nosjean O, Briolay A, Roux B. (1997) Mammalian GPI proteins: sorting, membrane residence and functions. Biochim. Biophys. Acta 1331: 153-186.

72. Müller G, Wetekam E-A, Jung C, Bandlow W. (1994) Membrane association of lipoprotein lipase and a cAMP-binding ectoprotein in rat adipocytes. Biochemistry 33: 12149-12159.

73. Müller G, Dearey E-A, Pünter J. (1993) The sulfonylurea drug, glimepiride, stimulates release of glycosyl-phosphatidylinositolanchored plasma membrane proteins from 3T3 adipocytes. Biochem. J. 289: 509-521.

74. Saltiel AR, Fox JA, Sherline P, Cuatrecasas P. (1986) Insulin stimulates the generation from hepatic plasma membranes of modulators derived from an inositol glycolipid. Science 233: 967-972.

75. Romero GL, Luttrell L, Rogol A, Zeller K, Hewlett E, Larner J. (1988) Phosphatidylinositol-glycan anchors of membrane proteins: potential precursors of insulin mediators. Science 240: 509511.

76. Müller G, Dearey E-A, Korndörfer A, Bandlow W. (1994) Stimulation of a glycosyl-phosphatidylinositol-specific phospholipase by insulin and the sulfonylurea, glimepiride, in rat adipocytes depends on increased glucose transport. J. Cell Biol. 126: 1267-1276.

77. Movahedi S, Hooper N. (1997) Insulin stimulates the release of the glycosyl phosphatidylinositol-anchored membrane dipeptidase from 3T3-Ll adipocytes through the action of a phospholipase C. Biochem. J. 326: 531-537.
78. Anderson RGW. (1998) The caveolae membrane system. Annu. Rev. Biochem. 67: 199-225.

79. Lisanti MP, Scherer PE, Tang ZL, Sargiacomo M. (1994) Caveolae, caveolin and caveolin-rich membrane domains: A signaling hypothesis. Trends Cell Biol. 4: 231-235.

80. Rothberg KG, Henser JE, Donzell WC, Ying YS, Glenney JR, Anderson RGW. (1992) Caveolin, a protein component of caveolae membrane coats. Cell 68: 673-682.

81. Parton RG. (1996) Caveolae and caveolins. Curr. Opin. Cell Biol. 8: 542-548.

82. Kurzchalia TV, Dupree P, Monier S. (1994) VIP-2 1 Caveolin, a protein of the trans-Golgi network and caveolae. FEBS Lett. 346: 8891.

83. Das K, Lewis RY, Scherer PE, Lisanti MP. (1999) The membrane-spanning domains of caveolins-1 and -2 mediate the formation of caveolin hetero-oligomers. J. Biol. Chem. 274: $18721-18728$.

84. Sargiacomo M, Scherer PE, Tang Z, Kübler E, Song KS, Sanders MC. (1995) Oligomeric structure of caveolin: Implications for caveolae membrane organizations. Proc. Natl. Acad. Sci. USA 92: 9407-9411.

85. Brown DA, London E. (1997) Breakthroughs and views. Structure of detergent-resistant membrane domains: does phase separation occur in biological membranes? Biochem. Biophys. Res. Commun. 240: 1-7.

86. Okamoto T, Schlegel A, Scherer PE, Lisanti MP. (1998) Caveolins, a family of scaffolding proteins for organizing "preassembled signaling complexes" at the plasma membrane. $J$. Biol. Chem. 273: 5419-5422.

87. Schlegel A, Volonte D, Engelmann JA. (1999) Crowded little caves: structure and function of caveolae. Cell. Signal. 10: 457-463.

88. Müller G, Frick W. (1999) Signalling via caveolin: Involvement in the cross-talk between phosphoinositolglycans and insulin. Cell. Mol. Life Sci. 56: 945-970.

89. Li S, Couet J, Lisanti MP. (1996) Src tyrosine kinases, Galpha subunits, and H-Ras share a common membrane-anchored scaffolding protein, caveolin. Caveolin binding negatively regulates the auto-activation of Src tyrosine kinases. J. Biol. Chem. 272: 2918229190.

90. Couet J, Sargiacomo M, Lisanti MP. (1997) Interaction of a receptor tyrosine kinase, EGF-R, with caveolins. Caveolin binding negatively regulates tyrosine and serine/threonine kinase activities. J. Biol. Chem. 272: 30429-30438.

91. Couet J, Li S, Okamoto T, Ikezu T, Lisanti MP. (1997) Identification of peptide and protein ligands for the caveolin-scaffolding domain. $J$. Biol. Chem. 272: 6525-6533.

92. Pulido N, Casla A, Suarez A, Casanova B, Arri- 
eta FJ, Rovira A. (1996) Sulphonylurea stimulates glucose uptake in rats through an ATPsensitive $\mathrm{K}^{+}$channel dependent mechanism. Diabetologia 39: 22-27.

93. Shi H, Moustaid-Moussa N, Wilkison WO, Zemel MB. (1999) Role of the sulfonylurea receptor in regulating human adipocyte metabolism. FASEB J. 13: 1833-1838.

94. Rajan A, Luo Z-T, Kahn BB, Comstock JP, Cushman SW, Boyd III AE. (1994) Do adipocytes contain high affinity sulfonylurea receptors? Endocrinology 134: 1581-1588.

95. Draznin B, Sussman KE, Eckel RH, Kao M, Yost T, Sherman NA. (1988) Possible role of cytosolic free calcium concentrations in mediating insulin resistance of obesity and hyperinsulinemia. J. Clin. Invest. 82: 1848-1852.

96. Draznin B, Kao M, Sussman KE. (1987) Insulin and glyburide increase cytosolic free- $\mathrm{Ca}^{2+} \mathrm{con}-$ centration in isolated rat adipocytes. Diabetes 36: 174-177.

97. Kim JH, Kiefer LL, Woychik RP, et al. (1997) Agouti regulation of intracellular clacium. Role of melanocortin receptor. Am. J. Physiol. 272: E379-E384.

98. Zemel MB, Kim LL, Woychik RP, et al. (1995) Agouti regulation of intracellular calcium: role in the insulin resistance of viable yellow mice. Proc. Natl. Acad. Sci. U.S.A. 92: 4733-4737.

99. Gribble FM, Tucker SJ, Seino S, Ashcroft FM. (1998) Tissue specificity of sulphonylureas: studies on cloned cardiac and $\beta$-cell $\mathrm{K}_{\mathrm{ATP}}$ channels. Diabetes 47: 1412-1418.

100. Smits P, Thien T. (1995) Cardiovascular effects of sulphonylurea derivatives. Implications for the treatment of NIDDM. Diabetologia 38: 116122.

101. Leibowitz G, Cerasi E. (1996) Sulphonylurea treatment of NIDDM patients with cardiovascular disease: a mixed blessing? Diabetologia 39: 503-515.

102. UKPDS. (1998) Intensive blood-glucose control with sulphonylureas or insulin compared with conventional treatment and risk of complications in patients with Type II diabetes (UKPDS 33). Lancet 352: 837-853.

103. Isomoto S, Kondo C, Yamada M. (1996) A novel sulphonylurea receptor forms with BIR (KIR6.2) a smooth muscle type of ATP-sensitive $\mathrm{K}^{+}$channels. J. Biol. Chem. 271: 2432 1-24325.

104. Ämmälä C, Moorhouse A, Gribble FM. (1996) Promiscuous coupling between the sulphonylurea receptor and inwardly-rectifying potassium channels. Nature 379: 545-548.

105. Geisen K, Hitzel V, Ökonomopulos R, Pünter J, Weyer R, Summ H-D. (1985) Inhibition of $\left[{ }^{3} \mathrm{H}\right]$ glibenclamide binding to sulfonylurea receptors by oral antidiabetics. Drug Res. 35: 707-712.

106. Dunn-Meynell A, Rawson N, Levin B. (1998)
Distribution and phenotype of neurons containing the ATP-sensitive $\mathrm{K}^{+}$channel in rat brain. Brain Res. 814: 41-54.

107. Spanswick D, Smith M, Groppi V, Logam S, Ashford ML. (1997) Leptin inhibits hypothalamic neurons by activation of ATP-sensitive potassium channels. Nature 390: 52 1-525.

108. Harvey J, McKenna F, Herson PS, Spanswick D, Ashford ML. (1997) Leptin activates ATPsensitive potassium channels in the rat insulinsecreting cell line, CRI-Gl. J. Physiol. 504: 527-535.

109. Considine RV, Caro JF. (1997) Leptin and the regulation of body weight. Int. J. Biochem. Cell Biol. 29: 1255-1272.

110. Tartaglia LA. (1997) The leptin receptor. J. Biol. Chem. 272: 6093-6096.

111. Schwartz MW, Woods SC, Porte D, Seeley RJ, Baskin DG. (2000) Central nervous system control of food intake. Nature 404: 661-671.

112. Harvey J, Ashford ML. (1998) Diazoxide- and leptin-activated K(ATP) currents exhibit differential sensitivity to englitazone and ciclazindol in the rat CRI-Gl insulin-secreting cell line. Brit. Pharmacol. 124: 1557-1565.

113. Harvey J, Ashford ML. (1998) Role of tyrosine phosphorylation in leptin activation of ATPsensitive $\mathrm{K}^{+}$channels in the rat insulinoma cell line CRI-G1. J. Physiol. 510: 47-61.

114. Harvey J, Ashford ML. (1998) Insulin occludes leptin activation of ATP-sensitive $\mathrm{K}^{+}$channels in rat CRI-Gl insulin secreting cells. J. Physiol. 511: 695-706.

115. Mastick CC, Brady MJ, Saltiel AR. (1995) Insulin stimulates the tyrosine phosphorylation of caveolin. J. Cell Biol. 129: 1523-1531.

116. Saad MJA, Velloso LA, Carvalho CRO. (1995) Angiotensin II induces tyrosine phosphorylation of insulin receptor substrate 1 and its association with phosphatidylinositol 3-kinase in rat heart. Biochem. J. 310: 741-744.

117. Kowalski-Chauvel A, Pradayrol L, Vaysse N, Seva C. (1996) Gastrin stimulates tyrosine phosphorylation of insulin receptor substrate 1 and its association with Grb2 and the phosphatidylinositol 3-kinase. J. Biol. Chem. 271: 26356-26361.

118. Argetsinger LS, Hsu GW, Myers MG, Billestrup N, White MF, Carter-Su C. (1995) Growth hormone, interferon- $\gamma$, and leukemia inhibitory factor promoted tyrosyl phosphorylation of insulin receptor substrate-1. J. Biol. Chem. 270: 14685-14692.

119. Verdier F, Chretien S, Billat C, Gisselbrecht S, Lacombe C, Mayeux P. (1997) Erythropoietin induces the tyrosine phosphorylation of insulin receptor substrate-2. J. Biol. Chem. 272: 26173-26178.

120. Lazar DF, Knez JJ, Medof ME, Cuatrecasas P, Saltiel AR. (1994) Stimulation of glycogen 
synthesis by insulin in human erythroleukemia cells requires the synthesis of glycosyl-phosphatidylinositol. Proc. Natl. Acad. Sci. USA 91: 9665-9669.

121. Jones DR, Varela-Nieto I. (1998) The role of glycosyl-phosphatidylinositol in signal transduction. Int. J. Biochem. Cell Biol. 30: 313-326.

122. Jones DR, Varela-Nieto I. (1999) Diabetes and the role of inositol-containing lipids in insulin signaling. Mol. Med. 5: 505-514.

123. Larner J, Huang LC. (1999) Identification of a novel inositol glycan signaling pathway with significant therapeutic relevance to insulin resistance: an insulin signaling model using both tyrosine kinase and G-proteins. Diabetes Rev. V7 N3: 217-231.

124. Frick W, Bauer A, Bauer J, Wied S, Müller G. (1998) Structure-activity relationship of synthetic phosphoinositolglycans mimicking metabolic insulin action. Biochemistry 38: $13421-$ 13436.

125. Frick W, Bauer A, Bauer J, Wied S, Müller G. (1998) Insulin-mimetic signalling of synthetic phosphoinositolglycans in isolated rat adipocytes. Biochem. J. 336: 163-181.

126. Müller G, Wied S, Piossek C, Bauer A, Bauer J, Frick W. (1998) Convergence and divergence of the signaling pathways for insulin and phosphoinositolglycans. Mol. Med. 4: 299-323.

127. Müller G, Wied S, Frick W. (2000) Cross talk of pp $125^{\mathrm{FAK}}$ and pp59 $9^{\mathrm{Lyn}}$ non-receptor tyrosine kinases to insulin-mimetic signaling in adipocytes. Mol. Cell. Biol. 20: 4708-4723.

128. Badian M, Korn A, Lehr K-H. (1994) Absolute bioavailability of glimepiride (Amaryl registered) after oral administration. Drug Metab. Drug Interact. 11: 331-339.

129. Rosenkranz B, Profozic V, Metelko Z. (1996) Pharmacokinetics and safety of glimepiride at clinically effective doses in diabetic patients with renal impairment. Diabetologia 39: 1617-1624.

130. Lehr KH, Damm P. (1990) Simultaneous determination of the sulfonylurea glimepiride and its metabolites in human serum and urine by high-performance liquid chromatography after pre-column derivatization. J. Chromatogr. 526: 497-505.

131. Wernicke-Panten K, Haupt E, Pfeiffer C. (1994) Early onset of pharmacodynamic effects of glimepiride in type II diabetic patients [abstract]. Diabetologia 37 (Suppl. 1): 163.

132. Rosenstock J, Samols E, Muchmore DB. (1996) Glimepiride, a new once-daily sulfonylurea: a double-blind placebo-controlled study of NIDDM patients. Diabetes Care 19: 1194-1199.

133. Sonnenberg GE, Garg DC, Weidler DJ. (1997) Short-term comparison of once-versus twicedaily administration of glimepiride in patients with non-insulin-dependent diabetes mellitus. Ann. Pharmacother. 31: 671-676.

134. Geisen K, Vegh A, Krause E. (1996) Cardiovascular effects of conventional sulfonylureas and glimepiride. Horm. Metab. Res. 28: 496-507.

135. Ballagi-Pordany G, Nemeth M, Aranyi Z. (1992) Effect of glimepiride on the electrical activity of isolated rabbit heart muscle. Drug Res. 42: 111-113.

136. Müller G, Ertl J, Gerl M, Preibisch G. (1997) Leptin impairs metabolic actions of insulin in isolated rat adipocytes. J. Biol. Chem. 272: 10585-10593.

137. Müller G, Wied S, Crecelius A, Kessler A, Eckel J. (1997) Phosphoinositolglycan-peptides from yeast potently induce metabolic insulin actions in isolated rat adipocytes, cardiomyocytes, and diaphragms. Endocrinology 138: 3459-3475.

138. Grynkiewicz G, Pocnic M, Tsien RY. (1985) A new generation of $\mathrm{Ca}^{2+}$ indicators with greatly improved fluorescent properties. J. Biol. Chem. 260: 3440-3450.

139. Zerangue N, Schwappach B, Jan YN, Jan LY. (1999) A new ER trafficking signal regulates the subunit stoichiometry of plasma membrane K(ATP) channels. Neuron 22: 537-548.

140. Müller G, Wied S, Welte S. (2000) Involvement of caveolae in insulin-mimetic signaling by the sulfonylurea Amaryl. Chem. Phys. Lipids 7: 7-8 [abstract]. 